\title{
Changes in Mediterranean circulation and water characteristics due to restriction of the Atlantic connection: a high-resolution ocean model
}

\author{
R. P. M. Topper ${ }^{1, *}$ and P. Th. Meijer ${ }^{1}$ \\ ${ }^{1}$ Department of Earth Sciences, Utrecht University, Budapestlaan 4 3584CD Utrecht, the Netherlands \\ "now at: MARUM - Center for Marine Environmental Sciences and Department of Geosciences, University of Bremen, \\ P.O. Box 330440, 28334, Germany
}

Correspondence to: R. P. M. Topper (rtopper@marum.de)

Received: 27 June 2014 - Published in Clim. Past Discuss.: 25 July 2014

Revised: 14 January 2015 - Accepted: 26 January 2015 - Published: 16 February 2015

\begin{abstract}
A high-resolution parallel ocean model is set up to examine how the sill depth of the Atlantic connection affects circulation and water characteristics in the Mediterranean Basin. An analysis of the model performance, comparing model results with observations of the present-day Mediterranean, demonstrates its ability to reproduce observed water characteristics and circulation (including deep water formation). A series of experiments with different sill depths in the Atlantic-Mediterranean connection is used to assess the sensitivity of Mediterranean circulation and water characteristics to sill depth. Basin-averaged water salinity and, to a lesser degree, temperature rise when the sill depth is shallower and exchange with the Atlantic is lower. Lateral and interbasinal differences in the Mediterranean are, however, largely unchanged. The strength of the upper overturning cell in the western basin is proportional to the magnitude of the exchange with the Atlantic, and hence to sill depth. Overturning in the eastern basin and deep water formation in both basins, on the contrary, are little affected by the sill depth.

The model results are used to interpret the sedimentary record of the Late Miocene preceding and during the Messinian Salinity Crisis. In the western basin, a correlation exists between sill depth and rate of refreshment of deep water. On the other hand, because sill depth has little effect on the overturning and deep water formation in the eastern basin, the model results do not support the notion that restriction of the Atlantic-Mediterranean connection may cause lower oxygenation of deep water in the eastern basin. However, this discrepancy may be due to simplifications in the
\end{abstract}

surface forcing and the use of a bathymetry different from that in the Late Miocene. We also tentatively conclude that blocked outflow, as found in experiments with a sill depth $\leq 10 \mathrm{~m}$, is a plausible scenario for the second stage of the Messinian Salinity Crisis during which halite was rapidly accumulated in the Mediterranean.

With the model setup and experiments, a basis has been established for future work on the sensitivity of Mediterranean circulation to changes in (palaeo-)bathymetry and external forcings.

\section{Introduction}

Ever since the closure of the connection to the Indian Ocean in the Middle Miocene, water exchange between the Mediterranean Sea and the global ocean has been through one or multiple gateways in the Gibraltar arc (e.g. Dercourt et al., 2000). In the Mediterranean, the water loss by evaporation exceeds, on an annual basis, the fresh water input from precipitation and river input. The resulting fresh water deficit, i.e. evaporation - precipitation - river input, is compensated for by a net inflow from the Atlantic. Without a connection to the global ocean, the deficit would not be replenished and Mediterranean sea level would rapidly drop (Meijer and Krijgsman, 2005). At present, the fresh water deficit in combination with the relatively small connection to the Atlantic results in a higher salinity in the Mediterranean than in the Atlantic. This salinity difference, and hence density differ- 
ence, between the Mediterranean and Atlantic drives a deep outflow of Mediterranean water. The outflow is compensated for with an inflow of less saline Atlantic water at the surface (e.g. Bryden and Kinder, 1991; Astraldi et al., 1999).

This pattern of surface inflow and deep outflow is known as anti-estuarine and has been the dominant mode of exchange since at least the closure of the Indian Ocean connection (Karami et al., 2011; Seidenkrantz et al., 2000; de la Vara et al., 2015). On a geological time scale, the fresh water budget of the Mediterranean has changed in accord with global climate. Superimposed on long-term variations are orbitally driven changes on shorter timescales. Precession and eccentricity have been shown to have a significant impact on Mediterranean river discharge, evaporation and precipitation (e.g. Tuenter et al., 2003). Due to the small exchange with the Atlantic, precessional changes in the fresh water budget have a pronounced effect on the Mediterranean circulation. The Mediterranean sedimentary record contains evidence for reduced bottom water ventilation during periods of precession-induced increased river discharge in the form of sapropels since the Miocene (Hilgen et al., 1995; Cramp and O’Sullivan, 1999).

In the Neogene and Quaternary sedimentary record, the occurrence of sapropels has been related to relatively strong precession minima, clustered in intervals with particularly high eccentricity (100 and $400 \mathrm{kyr}$ cycle). However, at the end of the Miocene (7.16-5.332 Ma), sapropels were formed in nearly every precession cycle (Seidenkrantz et al., 2000), indicative of a heightened sensitivity of Mediterranean circulation to its fresh water budget. Within an interval of increasing bottom water salinity starting at $\approx 8 \mathrm{Ma}$, a sharp change in the foraminiferal assemblage and a shift in $\delta^{13} \mathrm{C}$ at 7.16 Ma indicate reduced bottom water ventilation in several relatively deep marginal basins of the Mediterranean (Seidenkrantz et al., 2000; Kouwenhoven et al., 2003; Kouwenhoven and van der Zwaan, 2006). Low oxygen and high salinity conditions expand from deep marginal basins to marginal basins at shallower depths towards the onset of the Messinian Salinity Crisis (MSC; (Gennari et al., 2013)). The concurrent increase in sensitivity to changes in the fresh water budget, the increase in salinity, and the drop in bottom water ventilation, have been interpreted as indicators of reduced exchange with the Atlantic due to tectonically driven restriction of the Atlantic-Mediterranean connection (Kouwenhoven and van der Zwaan, 2006).

The ultimate expression of a strong tectonically driven restriction in Atlantic-Mediterranean exchange is the MSC, an event which is represented in the sedimentary record by widespread and voluminous evaporites in the Mediterranean. Circum-Mediterranean climate changed little during this event (Fauquette et al., 2006; Bertini, 2006), corroborating the results of model studies that demonstrate that a restriction of the Atlantic-Mediterranean connection can be the sole driver of the MSC (Topper et al., 2011; Topper and Meijer, 2013). A vast halite layer (1-2 km in the deep basins) formed during the short second phase of the MSC (5.61-5.55 Ma, Roveri and Manzi, 2006). A scenario with inflow from the Atlantic but no outflow, the so-called blocked-outflow scenario, has been proposed to explain the fast accumulation of salt in the Mediterranean (Krijgsman et al., 1999a; Meijer, 2006; Krijgsman and Meijer, 2008). According to hydraulic control theory, blocked outflow can be attained in the Atlantic-Mediterranean gateway when the water depth is just a few metres (Meijer, 2012).

In the Late Miocene, Atlantic-Mediterranean exchange occurred through two shallow marine gateways in northern Morocco and southern Spain, respectively the Rifian and Betic corridors (Benson et al., 1991; Betzler et al., 2006). Due to their geometry, i.e. shallow, wide and long, and position at the interface of ongoing Africa-Eurasia convergence, these gateways were vulnerable to changes in width and depth by tectonics (Duggen et al., 2003; Weijermars, 1988; Govers, 2009). Opening and closure of both gateways is recorded in the sedimentary record of the subbasins that make up the corridors. Closure of the Rifian corridor took place somewhere in the interval 6.8-6.0 Ma (Krijgsman et al., 1999b; Ivanovic et al., 2013; van Assen et al., 2006). The Betic corridor has long thought to have been closed by 7.8 Ma (Soria et al., 1999; Betzler et al., 2006; Martín et al., 2009). Recent work has disputed this, stating that the Betic corridor might have been open after $7.8 \mathrm{Ma}$ (Hüsing et al., 2010; Pérez-Asensio et al., 2012). Wherever the connection may have been, the volume of evaporites formed during the MSC can only be explained by a continued inflow of saline water from the Atlantic (Sonnenfeld and Finetti, 1985; Krijgsman and Meijer, 2008; Topper and Meijer, 2013).

The purpose of this study is to examine with a highresolution ocean circulation model how sill depth of the Atlantic connection, influenced by long-term tectonics, affects circulation and water characteristics in the Mediterranean Basin. The physics-based insight thus gained is used to evaluate the Late Miocene sedimentary record: that of the MSC and, in particular, that of the period just preceding the actual crisis. Notwithstanding our focus on the Late Miocene, the basin bathymetry is - except near the Atlantic connection - that of the present Mediterranean Sea. The reasons for this are that (1) we isolate the changes in circulation and water characteristics that are caused by a different depth of the Atlantic connection, and (2) a validation of model performance is only possible in a present-day model setup because quantitative data on water properties and circulation does not exist for other time periods. Such an assessment of model performance is necessary because the model has not been applied to the Mediterranean before. Thus taking the present-day bathymetry as our reference, the depth of the Strait of Gibraltar is modified to gain insight into the role of depth of the Atlantic connection. Even though basin shape was different in the Late Miocene and the connection to the ocean had a different geometry and location, our model results form a good starting point for this past time as well. 
The reason for this is that, in terms of features that govern the overall circulation and water properties, the present-day and Late Miocene basin geometry are largely similar. Both consist of two subbasins, comprise limited shelf areas and deep-basinal portions, are subject to net evaporation and possess parts located at relatively high latitude where cooling of the surface water occurs. Thus, insight gained about the change in circulation and water properties due to variation in sill depth is expected to be largely generic. A minimal model of the Mediterranean with a highly idealized surface forcing has been shown to be able to capture the important characteristics of Mediterranean circulation (Meijer and Dijkstra, 2009). A similar idealized surface forcing is applied in this study, a simplification of the model setup that is justified when the focus is on the influence of the sill depth.

Water exchange in the present-day Strait of Gibraltar has been studied extensively because of its influence on Mediterranean water characteristics and, therewith, circumMediterranean climate (Bryden and Stommel, 1984; Sannino et al., 2002; Astraldi et al., 1999; Hopkins, 1999; Candela, 1991; Bryden et al., 1994). The present-day Mediterranean circulation and the influence of temporal variations in the surface forcing, e.g. fresh water budget and heat flux, has also been widely studied, often in the context of sapropels (Meijer and Tuenter, 2007; Meijer and Dijkstra, 2009; Samuel et al., 1999; Myers et al., 1998a, b; Myers, 2002). Data and simple modelling studies have demonstrated the importance of the size of the Atlantic-Mediterranean connection in controlling sedimentation and circulation in the Mediterranean. Recently, ocean circulation models have been used to investigate the influence of gateway geometry on water characteristics and circulation in an idealized marginal basin (Iovino et al., 2008; Pratt and Spall, 2008) and realistic marginal basins, e.g. the Miocene Arctic Ocean (Thompson et al., 2010). Similar studies, regarding the influence of gateway geometry on Mediterranean circulation and water characteristics, are, as yet, few in number. The sensitivity of circulation in the Late Miocene Mediterranean to changes in the palaeogeography has been examined by Meijer et al. (2004). More recently, Alhammoud et al. (2010) have examined how the sill depth of the Strait of Gibraltar affects the thermohaline circulation in a highly idealized coarse resolution ocean circulation model.

The next section will provide a description of the model and boundary conditions used. In Sect. 3, the results of a reference experiment with the present-day sill depth will be compared to water characteristics and circulation as observed or modelled for the present-day Mediterranean to assess model performance. Keeping all other boundary conditions constant, the sill depth of the Atlantic gateway will be both increased, up to $500 \mathrm{~m}$, and reduced, down to $5 \mathrm{~m}$, in a series of experiments. Model results will be discussed in the context of the Late Miocene restriction of the AtlanticMediterranean connection and the blocked-outflow scenario for the MSC.
Table 1. Overview of parameter values used to set up the model. SIUS: Smolarkiewicz iterative upstream scheme.

\begin{tabular}{llc}
\hline Parameter & Detail & Value \\
\hline tprni & Inverse Prandtl number & 0.2 \\
horcon & Smagorinsky diffusivity coefficient & 0.2 \\
nitera & Number of iterations of the SIUS & 2 \\
$\mathrm{sw}$ & Smoothing parameter of the SIUS & 0.8 \\
$t_{\mathrm{E}}$ & External (2-D) time step & $30 \mathrm{~s}$ \\
$t_{\mathrm{I}}$ & Internal (3-D) time step & $1800 \mathrm{~s}$ \\
$t_{\text {RELAX }}$ & Relaxation time scale of surface temperature forcing & 1 day \\
\hline
\end{tabular}

\section{Model description}

For a good representation of water exchange through a shallow gateway, a model with a high number of vertical layers in shallow water is required. A model with vertical sigma coordinates meets this requirement better than a model with $z$ coordinates. With sigma coordinates, regardless of water depth, the number of vertical grid points in the water column is equal. The distance between vertical grid points is a percentage of the total water depth at each point, i.e. layers are further apart in deep water than in shallow water. In this study, we use sbPOM (Jordi and Wang, 2012), a recently developed parallel, free-surface, sigma-coordinate, primitive equations ocean modelling code based on the Princeton Ocean Model (Blumberg and Mellor, 1987). Differences between sbPOM and the 2008 version of POM only concern the parallelization: the code is rearranged in several files and a messagepassing interface using two-dimensional data decomposition of the horizontal domain has been implemented. POM has been applied extensively to the Mediterranean and the Strait of Gibraltar (e.g. Zavatarelli and Mellor, 1995; Ahumada and Cruzado, 2007; Jungclaus and Mellor, 2000; Drakopoulos and Lascaratos, 1999; Alhammoud et al., 2010; Sannino et al., 2002; Beckers et al., 2002). In an application to the Mediterranean, POM is set up with a true evaporation instead of a virtual salt flux. Evaporative water loss in the Mediterranean therefore drives a net flow through the Atlantic gateway which is necessary for a realistic representation of exchange.

Vertical mixing coefficients are calculated in the model with the Mellor and Yamada (1982) level 2.5 turbulence closure scheme. The pressure gradient scheme used is a fourth order scheme using the McCalpin method (Berntsen and Oey, 2010). The inverse Prandtl number, the ratio between horizontal mixing coefficients for diffusivity and viscosity (calculated with a Smagorinsky formulation), has been set to 0.2. This and other model parameters, chosen after an extensive sensitivity study, are listed in Table 1 . The model parameter with the largest impact on model results proves to be the smoothing parameter of the Smolarkiewicz iterative upstream scheme.

The bathymetry used in this study (Fig. 1) derives from the 1 min resolution global surface (ETOPO1) provided by the 


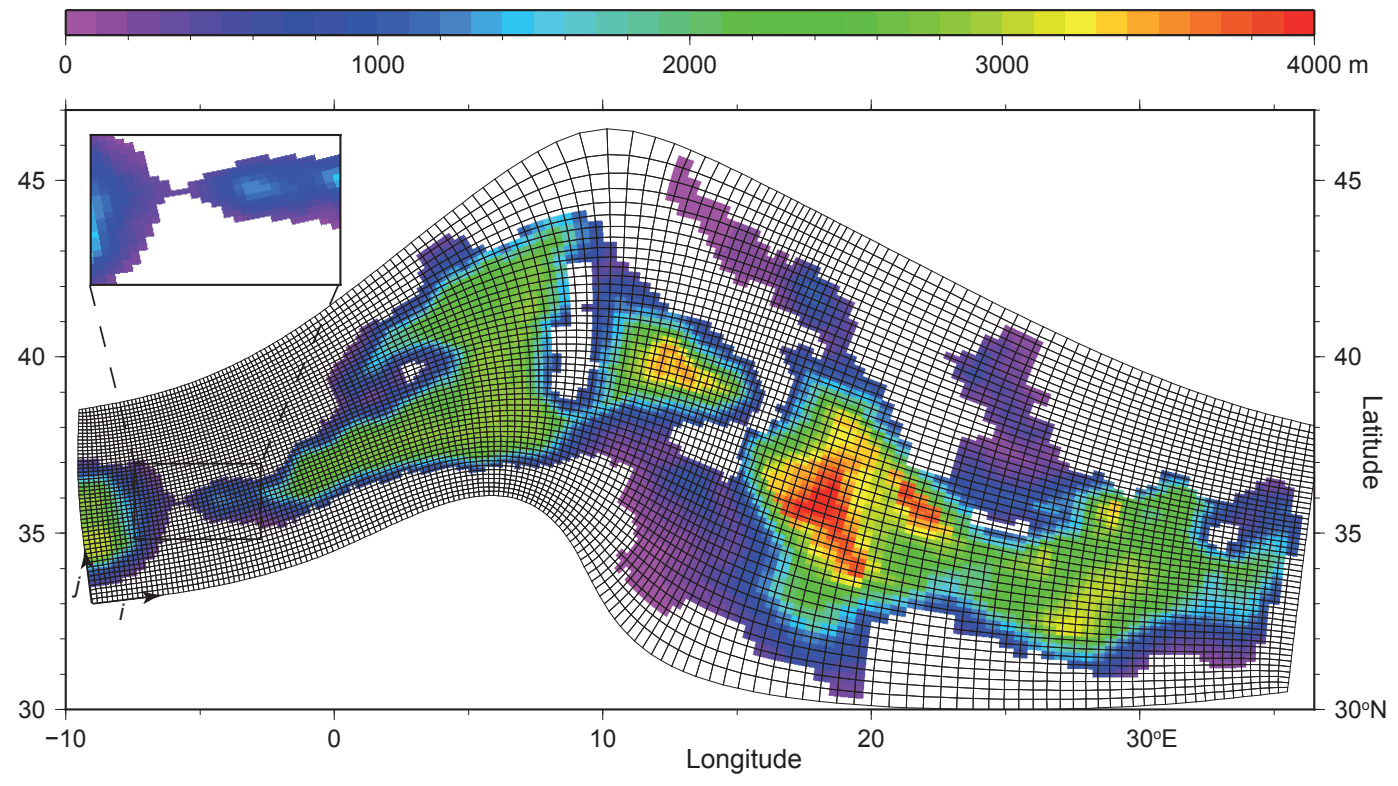

Figure 1. Model grid and bathymetry. Curvilinear grid coordinates $i$ and $j$ increase along curved lines towards, roughly, the east and north. The small inset shows the geometry of the Strait of Gibraltar in more detail.

National Geographical Data Center of the NOAA (Amante and Eakins, 2009). In the model, a curvilinear grid is used in the horizontal, similar to that of Zavatarelli and Mellor (1995). A curvilinear grid has the advantages that it allows for variable horizontal resolution and a high percentage of grid points in the basin, i.e. less grid points are needed compared to a rectangular grid. Before interpolation of the bathymetry to the horizontal grid $(162 \times 50$ grid points), a Gaussian filter has been applied to remove short wavelength variations from the bathymetry. Furthermore, the parameter used to control the maximum slope between two adjacent grid cells is set to 0.15 in order to minimize pressure gradient errors and ensure model solution stability (Mellor et al., 1994). Horizontal grid resolution is highest near the Strait of Gibraltar and lowest in the eastern Mediterranean Basin. The minimum/maximum size of a grid cell in the $i \mathrm{di}$ rection (Fig. 1) and $j$ direction are respectively $11.7 / 62.9$ and $10.7 / 69.6 \mathrm{~km}$. The width of the Strait of Gibraltar is $12.9 \mathrm{~km}$, equal to its smallest width in the present day. The orientation of the curvilinear coordinates $(i$ and $j$ ) varies along the grid and deviates from the absolute longitudinal and latitudinal direction. For simplicity, the $i$ and $j$ directions along the curvilinear grid will be referred to as longitudinal and latitudinal, respectively. Likewise, we will take "zonal" to mean "along the curvilinear $i$ coordinate". In the vertical direction, the grid comprises 40 sigma levels. Grid points have the highest density near the surface and bottom in order to resolve the thermocline and bottom currents. In order to optimize the time step, maximum depth in the Atlantic part of the model is set to $3000 \mathrm{~m}$, and in the Mediterranean to $4000 \mathrm{~m}$. The maximum difference with the actual bathymetry is less than
$100 \mathrm{~m}$. In the current setup, the model can be integrated for $100 \mathrm{yr}$ in $28 \mathrm{~h}$ on 4 processors of an Intel Core i7-950 workstation running at $3.06 \mathrm{GHz}$ with $12 \mathrm{~GB}$ memory.

Initial conditions for temperature and salinity derive from Levitus' World Ocean Atlas (Antonov et al., 1998). In the Atlantic part of the model, temperature and salinity are horizontally averaged before interpolation to sigma coordinates to avoid density contrasts near the western boundary of the grid, which is an open boundary, and provides water of constant temperature and salinity at each depth near the Strait of Gibraltar.

The surface forcing is idealized and constant in time, and resembles the forcing used in Alhammoud et al. (2010). The surface water flux is a constant evaporation of $0.5 \mathrm{~m} \mathrm{yr}^{-1}$ over the whole model domain, a value close to presentday evaporation - precipitation - river input (Mariotti et al., 2002), but also suitable for the Late Miocene (Gladstone et al., 2007; Schneck et al., 2010). Sea surface temperatures are relaxed to a best fit for zonally and yearly averaged air temperatures from ECMWF data (Fig. 2 from Alhammoud et al., 2010). The relaxation time scale is 1 day; sensitivity experiments have shown that the relaxation time scale can be as long as 30 days before model results are significantly affected. Winds over the Mediterranean are highly variable throughout the year; a yearly averaged wind pattern is therefore unusable. Since wind stresses have been shown to affect only the strength of upper ocean circulation without changing the overall circulation pattern (Myers et al., 1998b; Meijer and Dijkstra, 2009), wind stresses have not been included.

The western boundary in the Atlantic part of the model domain is open. For the barotropic mode (2-D) a zero-gradient 

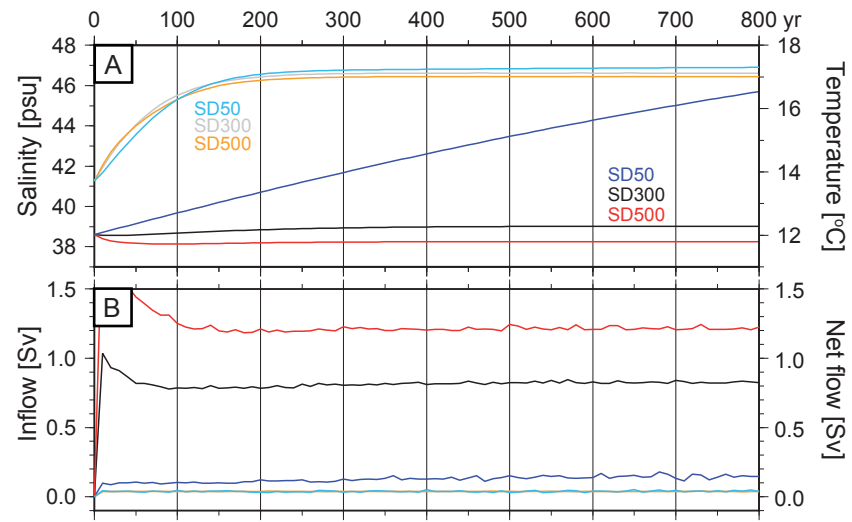

used to assess the role of sill depth only differ from the reference experiment in the sill depth and the bathymetry near the sill. The different experiments will be referred to as SD500 to SD5 according to their sill depth in metres. Each of the experiments has been run for $800 \mathrm{yr}$. The time needed to reach steady state conditions in an experiment is inversely proportional to the depth of the sill. As a consequence, experiments with a sill depth shallower than $100 \mathrm{~m}$ have not reached a steady state in $800 \mathrm{yr}$. This will be pointed out where it affects the results.

\subsection{Reference experiment}

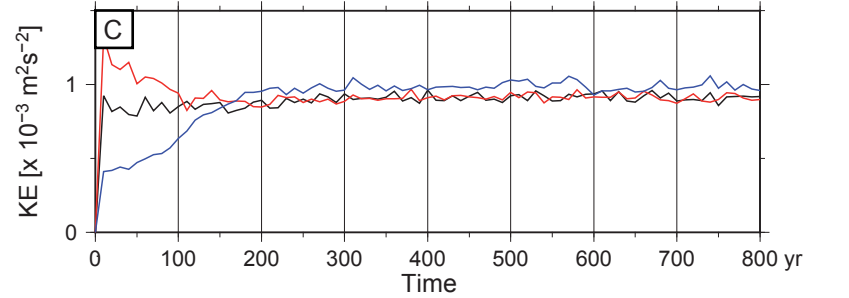

The temporal variation of basin-averaged temperature, salinity, a measure of kinetic energy, and strait transport is illustrated in Fig. 2 for the reference experiment (SD300). Temperature, salinity and kinetic energy are averaged in the Mediterranean part of the model domain, i.e. east of the Strait of Gibraltar at $-5.5^{\circ} \mathrm{E}$. The average basinal velocity squared is used as a measure of the kinetic energy which, in turn, gives an indication of the intensity of flow in the basin. In the first $300 \mathrm{yr}$ of the reference experiment, salinity and temperature move towards their respective steady state values of $39.02 \mathrm{psu}$ and $17.12^{\circ} \mathrm{C}$. At the same time, inflow through the Strait of Gibraltar also stabilizes at $0.83 \mathrm{~Sv}$ $\left(1 \mathrm{~Sv}=10^{6} \mathrm{~m}^{3} \mathrm{~s}^{-1}\right)$. The difference between inflow and outflow, the net flow, is equal to the fresh water deficit in the Mediterranean, $0.04 \mathrm{~Sv}$, from the start of the experiment. Salinity, temperature and strait transport all reach steady state values at the same time. This is the expected behaviour since salinity and temperature determine the density difference with the Atlantic, which, in turn, drives the exchange at Gibraltar. The kinetic energy measure reaches a value close to its steady state value within the first $100 \mathrm{yr}$ and slowly increases further towards a steady state, which is also reached at $300 \mathrm{yr}$.

At steady state a balance exists between the transport of heat and salt at the Strait of Gibraltar and the surface forcings in the Mediterranean, which is reflected by quasi-constant properties of the exchange. Velocity, temperature and salinity profiles from the Strait of Gibraltar are shown in Fig. 3. Relatively warm Atlantic water with a close to normal marine salinity flows eastwards through the Strait of Gibraltar in the upper layer, while more saline water flows westward at depth. The anti-estuarine circulation pattern observed in the present-day Strait of Gibraltar is thus reproduced. Moreover, the velocity profile is similar to observed velocity profiles at Camarinal Sill (e.g. Bryden et al., 1994; Tsimplis, 2000; Hopkins, 1999; Candela, 2001), velocity and salinity profiles of other model studies (Sannino et al., 2002; Xu et al., 2007), and theoretical velocity profiles (Hopkins, 1999). Small differences exist in the height of the interface and absolute velocities of inflow and outflow. These are mainly due to the idealized shape of the cross sectional area of the gateway in our model. The curves in Fig. 3 exhibit four features that are 

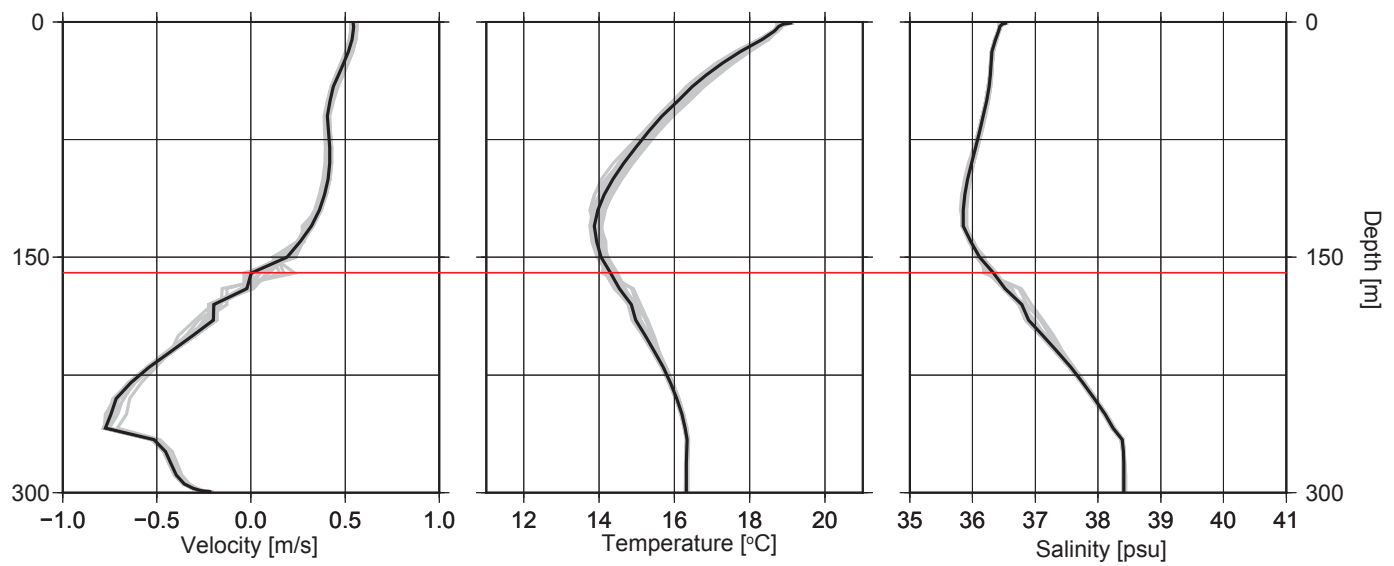

Figure 3. Vertical profiles of zonal velocity (left), temperature (middle), and salinity (right) in the middle of the Strait of Gibraltar in the reference experiment. Grey shading in each frame indicates the range of variation of the variable in the last $100 \mathrm{yr}$ of integration, the solid black line is the average over the same $100 \mathrm{yr}$. The red line indicates the depth of the interface between inflow and outflow.

noteworthy: (1) the depth of the interface between the inflow and outflow is not exactly halfway but slightly deeper $(165 \mathrm{~m}),(2)$ velocity changes gradually with depth, i.e. there is no sharp transition across the interface between inflow and outflow, (3) the maximum velocity in the outflow is higher than in the inflow because velocities are strongly reduced near the bottom, and (4) temperature and salinity gradually change with depth, indicating that mixing takes place between inflow and outflow in the strait. All four features are important when exchange in the experiments with different sill depths is compared to the exchange predicted by hydraulic control theory (Sect. 4.2).

Figure 4 illustrates the horizontal and vertical patterns of salinity and temperature in two horizontal slices at $10 \mathrm{~m}$ and $300 \mathrm{~m}$ and a vertical section crossing the whole domain from west to east. The inflowing Atlantic water starts to change its temperature and salinity in response to the surface forcing as soon as it enters the Mediterranean. At the surface, low saline Atlantic water can be traced along the southern coast into the eastern Mediterranean. The constant evaporation at the surface drives an increase in salinity towards the eastern basin, from 36.5 to 39 psu. Highest salinities are accordingly reached in the easternmost Mediterranean. Due to the strong surface temperature relaxation, surface temperatures are similar to the latitudinally decreasing air temperature in the larger part of the Mediterranean. Only the northern part of the western basin and the area directly east of the Sicily Strait deviate from this pattern. In both areas, advection of heat is faster than the surface forcing.

A difference in water characteristics does not only exist between the Atlantic and Mediterranean, a clear difference is also visible between western and eastern Mediterranean. The Sicily Strait restricts exchange between the basins. In combination with the fresh water deficit of the eastern Mediterranean, this drives an eastward surface flow and westward deep flow, i.e. an anti-estuarine circulation with respect to the western basin. The western basin has an average salinity of $38.3 \mathrm{psu}$, compared to $39.5 \mathrm{psu}$ in the eastern basin. In spite of the significantly higher surface temperatures in the eastern basin, differences in basin-averaged temperature are relatively small $\left(16.1\right.$ vs. $\left.17.5^{\circ} \mathrm{C}\right)$.

The circulation pattern evidenced by the salinity and temperature distribution in the Mediterranean is confirmed by the "zonal" overturning stream function which is calculated along the curvilinear coordinates (Fig. 5). A positive overturning cell, representing clockwise circulation in an W-E profile, extends from the Atlantic through the whole Mediterranean. The vertical extent and strength of the positive overturning cell is larger in the western than in the eastern Mediterranean. At depth a negative overturning cell is present in both basins with a larger vertical extent and strength in the eastern basin.

On the vertical temperature and salinity profiles, the area east of $25^{\circ} \mathrm{E}$ stands out due to its significantly higher salinity and temperature at depths up to $500 \mathrm{~m}$. The zonal overturning stream function confirms that this is an area of downwelling. Following the approach from other studies (Dijkstra, 2008; Ezer and Mellor, 1997; Alhammoud et al., 2010), the rate of intermediate water formation can be derived from the stream function. In the area east of $25^{\circ} \mathrm{E}$, the rate of intermediate water formation is $0.75 \mathrm{~Sv}$. The maximum rate of Levantine Intermediate Water formation in this area is estimated at $1.2 \mathrm{~Sv}$ (Lascaratos and Nittis, 1998), slightly higher than our estimate. The tilted isotherm in the deep eastern basin is consistent with intermediate and deep water formation in the eastern part of the basin. The inclined isohalines in the upper $300 \mathrm{~m}$ of the western basin are not caused by vertical water movements but by the flow of more saline water from the eastern basin to the west.

For further analysis of the intermediate and deep water formation, Fig. 6a shows the distribution of the average mixed layer depth. The average mixed layer depth is relatively shal- 

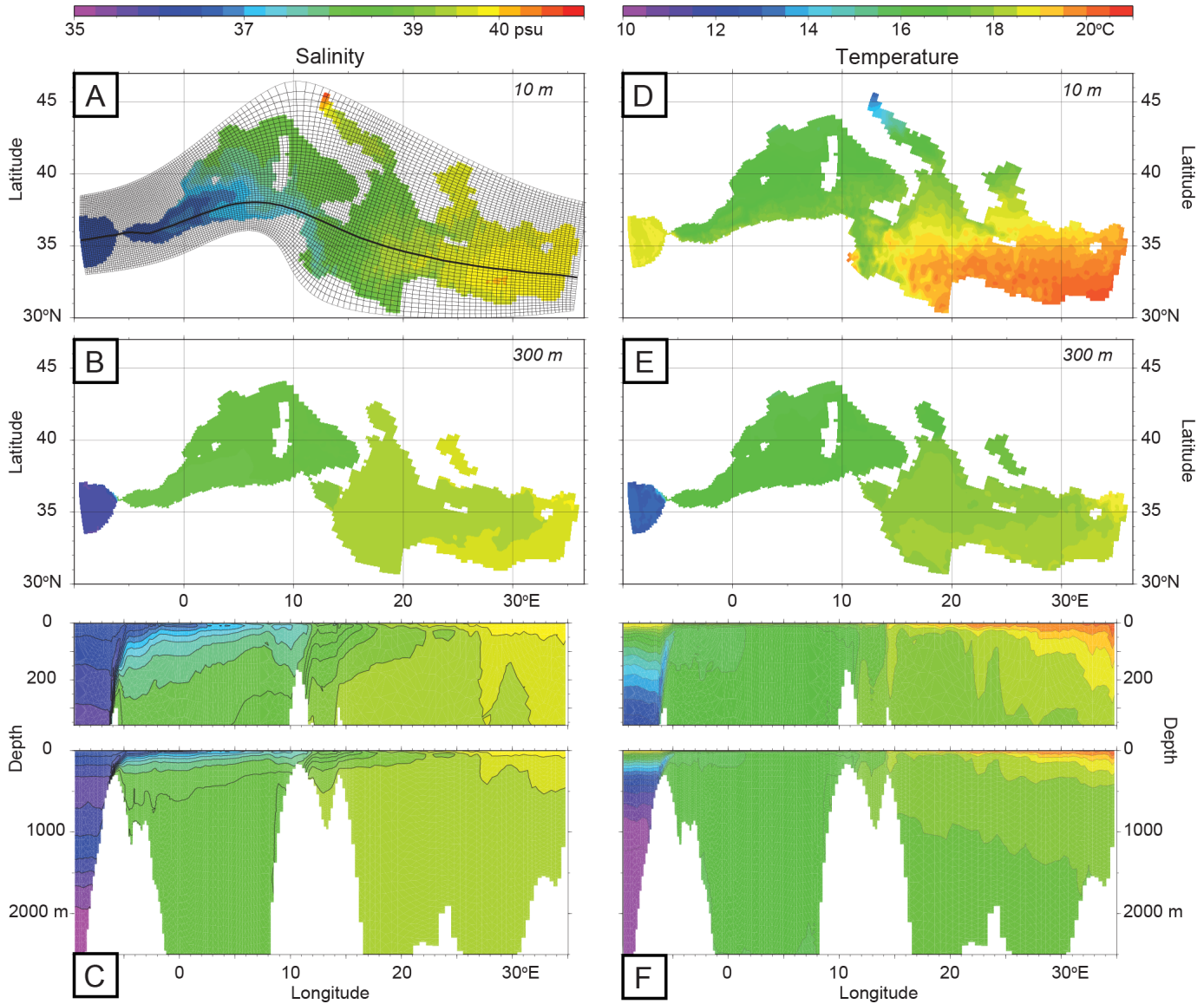

Figure 4. Two horizontal and a vertical cross section through the three-dimensional salinity (a, c, e) and temperature (b, d, f) fields averaged over the last $10 \mathrm{yr}$ of the reference experiment. Horizontal slices are shown in the surface layer $(10 \mathrm{~m})$ and at the sill depth of the Strait of Gibraltar $(300 \mathrm{~m})$. The vertical cross section is along the curved path indicated in (a) that crosses both the Gibraltar and Sicily straits.

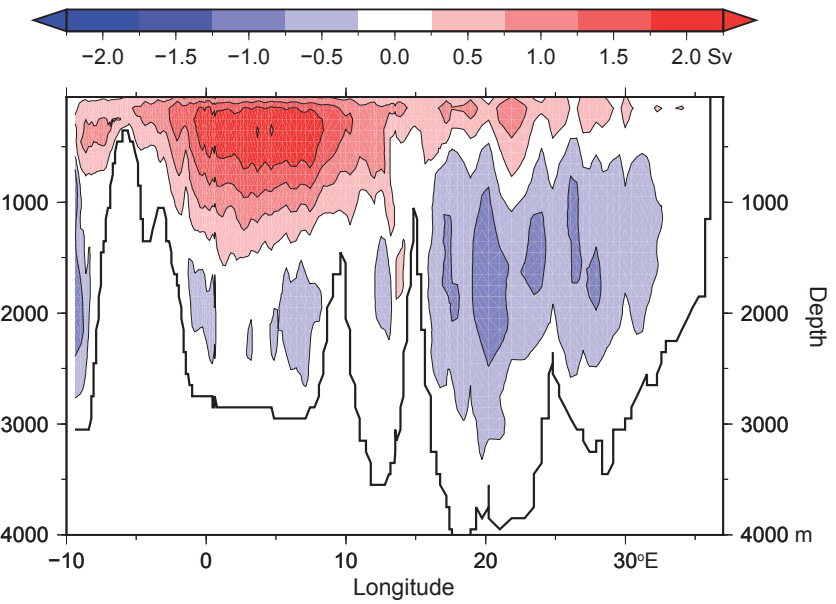

Figure 5. "Zonal" overturning stream function of the reference experiment. The contour interval is $0.5 \mathrm{~Sv}$. Positive values (red colours) indicate clockwise circulation in this view, negative values (blue) anti-clockwise circulation. low because of a high spatial and temporal variability in the mixed layer depth, i.e. mixed layer depths often vary between almost zero and the maximum shown in Fig. 6b. Hence, the maximum mixed layer depth can be used to illustrate the variation in depth and location of the intermediate and deep water formation sites. Deep water formation occurs where the mixed layer is anomalously deep, e.g. the northern part of the western basin where mixing occurs up to $3000 \mathrm{~m}$, and where the mixed layer depth (nearly) equals the water depth, as in the Adriatic Sea, the Aegean Sea and the north-east corner of the Levantine Basin. Figure 6 shows the path of water particles that have been tracked for 30 days in the lowest sigma layer, i.e. the bottom currents. The idea of visualizing bottom velocities to track dense water currents is taken from Zavatarelli and Mellor (1995). Where dense water is formed in shallow areas, it flows downslope to the deep basin until it reaches a depth where its density equals that of the water at that depth. While dense water from the Adriatic clearly reaches large depths, dense water from the Aegean only reaches intermediate depths. In addition to deep water formation and dense water currents flowing into the 

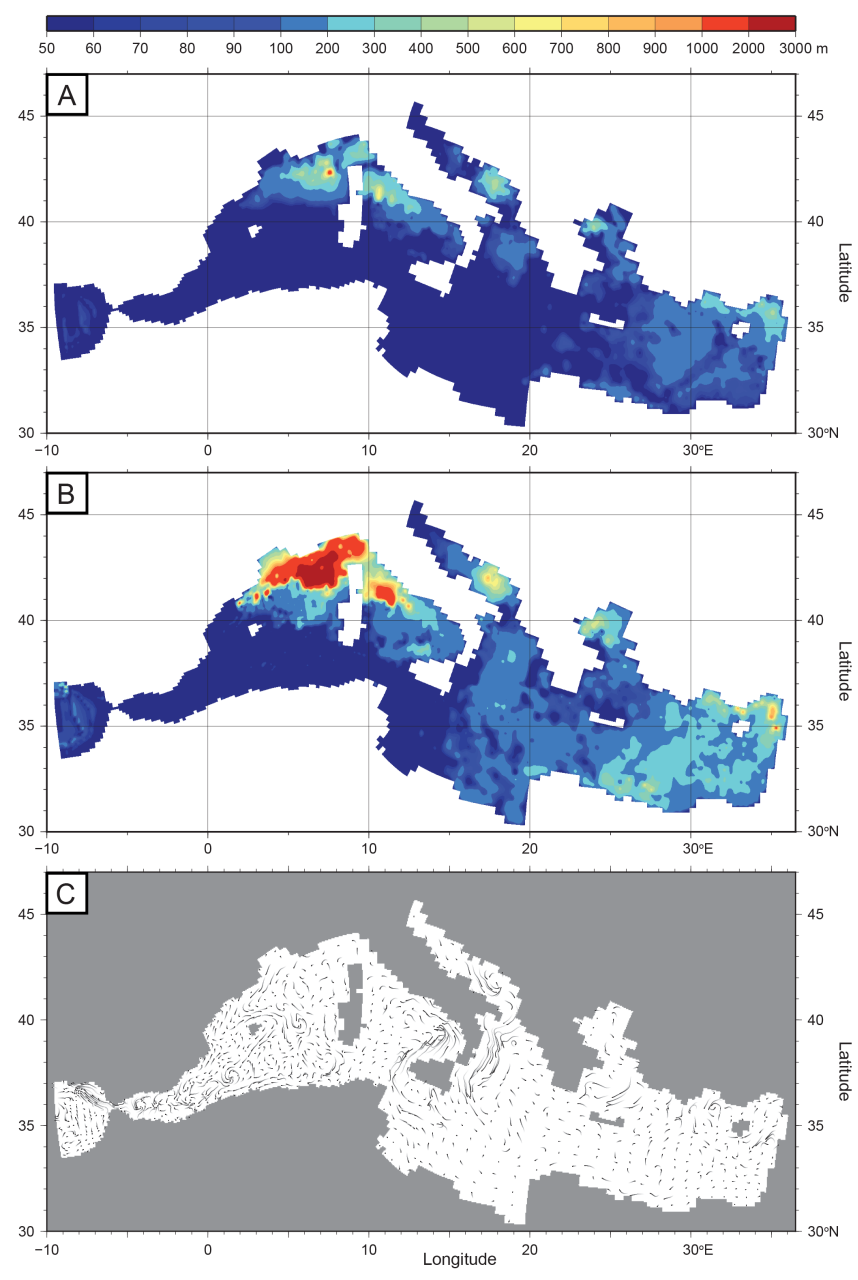

Figure 6. The average (a) and maximum (b) mixed layer depth, calculated from the last $50 \mathrm{yr}$ of integration, and bottom currents (c) in the reference experiment. The mixed layer depth is defined as the depth, measured from the surface, of the minimum vertical mixing parameter. Bottom currents are visualized by tracking water particles for 30 days in the average velocity field of the last $10 \mathrm{yr}$ of integration. Trajectories start at light grey and proceed to black at the 30th day.

deep basin, Fig. 6 also shows the trajectories of dense water flowing from the eastern to the western basin and from the Mediterranean to the Atlantic. The northward deflection of both westward directed flows is due to the Coriolis effect.

\subsubsection{Model results compared to present-day observations}

Initial conditions in the model are based on recent observations of salinity and temperature (Levitus fields). Therefore, the difference between initial and steady state salinity and temperature is equal to the difference between modelled and observed values. Due to the simple constant surface forcings, we cannot expect to capture annual variability in circulation and deep water formation. Basin-averaged temperatures are $3.4^{\circ} \mathrm{C}$ higher than observed $\left(17.12\right.$ vs. $\left.13.71^{\circ} \mathrm{C}\right)$. The bulk of this difference can be ascribed to significantly higher deep water temperatures. Temperature differences near the surface are comparatively small and, because only $10 \%$ of the basinal volume is contained in the surface layer, do not significantly affect basin averages.

In the present-day Mediterranean, deep water formation is strongest during the winter months (e.g. Lascaratos et al., 1999). Hence, most deep water is formed when sea surface temperatures are below the annual average. The use of mean annual air temperatures in our model gives rise to deep water formation throughout the year and an associated overestimation of deep water temperatures. Basin-averaged salinity, on the other hand, is close to the value from observations (39.0 vs. $38.6 \mathrm{psu}$ ). Annual variability of evaporation in the Mediterranean is small. The use of a constant evaporation rate is therefore a simplification of the surface forcing that does not significantly impact the basinal salinity. Furthermore, a model setup with a constant surface forcing provides a convenient starting point in unravelling a possible correlation between sill depth and the overturning.

Transport through the Strait of Gibraltar has been the subject of innumerable studies. Estimates have been based on observations, numerical modelling and hydraulic control theory. Given the uncertainty in the fresh water budget of the Mediterranean and the wide range of approaches, the volume transport at the Strait of Gibraltar has been estimated at $0.8-1.8 \mathrm{~Sv}$, with most recent estimates at the lower end of this range (e.g. Astraldi et al., 1999; Tsimplis and Bryden, 2000). The inflow of $0.83 \mathrm{~Sv}$ in the reference experiment is thus within this range. In a model with annual variation in the surface forcing, the low deep water temperatures observed in the Mediterranean are reproduced (unpublished results). Compared to the results of the reference experiment, lower deep water temperatures will lead to a small increase of exchange due to the resultant larger density contrast with the Atlantic. However, for the objective of examining the role of strait depth, water exchange with the Atlantic is sufficiently reproduced.

Often, basin-scale circulation models with realistic and idealized atmospheric forcing have had difficulties reproducing deep water formation and, in particular, deep overturning in the western basin (e.g. Meijer et al., 2004; Meijer and Dijkstra, 2009). The reference experiment, set up with idealized forcing, is able to produce both. It should, however, be noted that the locations of deep water formation in the model differ, especially in the western Mediterranean, from locations inferred from observations.

In a series of sensitivity experiments, deep water formation has been compared in models with different latitudinal gradients in the air temperature. With a reduced latitudinal air temperature gradient, the mixed layer depth is still largest in the northern part of the western basin, the Adriatic and the Aegean Sea. However, rates of deep water forma- 
tion and the strength of the deep overturning cell are lower while the formation of intermediate water in the eastern basin and the strength of the upper overturning cell in both basins are higher. These results are in agreement with Alhammoud et al. (2010) and Somot et al. (2006) who found that deep water formation is mainly controlled by the surface temperature forcing. These authors also found that intermediate water formation is mainly controlled by evaporation. A series of sensitivity experiments with different rates of evaporation confirms this.

The strength of the surface overturning cell in the reference experiment is slightly larger than in most other highresolution model studies (Meijer et al., 2004; Meijer and Dijkstra, 2009; Somot et al., 2006; Stratford et al., 2000; Adloff et al., 2011). The vertical and horizontal extent, however, is similar for both the western and eastern basin. Also, the ratio between minimum and maximum zonal overturning is equal to other studies at $\approx 0.33$. The results of a series of sensitivity experiments demonstrate that the degree of bathymetry smoothing, the maximum slope in the bathymetry and the smoothing parameter of the Smolarkiewicz scheme have a significant and predictable impact on the strength of circulation. In general, less smoothing, steeper slopes and a lower smoothing parameter result in a stronger overturning with more lateral variation. The bathymetry used here has relatively low maximum slopes and minimal smoothing while the smoothing parameter is relatively low.

The overall good agreement between observed and modelled strait transports, water characteristics and circulation, quantitatively as well as qualitatively, shows that the model setup of the reference experiment captures all important processes of the Mediterranean thermohaline circulation. Having validated the model setup of the reference experiment, we will describe in the next section the changes in Mediterranean water characteristics and circulation due to changes in the sill depth of the Atlantic connection.

\subsection{The role of sill depth}

The temporal variations of water characteristics and transport in two experiments with a shallow $(50 \mathrm{~m}, \mathrm{SD} 50)$ and deep $(500 \mathrm{~m}, \mathrm{SD} 500)$ gateway and the reference experiment can be compared in Fig. 2. The increase in basin-averaged temperature with run time in all three experiments is comparable in both magnitude and duration. A steady state is reached after $300 \mathrm{yr}$ with a slightly lower value for SD500 $\left(17.01^{\circ} \mathrm{C}\right)$ and a higher value for $\operatorname{SD} 50\left(17.30^{\circ} \mathrm{C}\right)$. The temporal variation of basin-averaged salinities, on the other hand, is significantly different. SD500 reaches a steady state within $100 \mathrm{yr}$ at $38.6 \mathrm{psu}$, SD50 does not reach a steady value within $800 \mathrm{yr}$. The average rate of salinity increase in SD50 is $8.9 \mathrm{psu} \mathrm{kyr}^{-1}$. However, the rate drops slowly with time; in the first $100 \mathrm{yr}$ it is $10.7 \mathrm{psu} \mathrm{kyr}^{-1}$, in the last $100 \mathrm{yr}$ "only" $6.8 \mathrm{psu} \mathrm{kyr}^{-1}$. When the density difference between Atlantic and Mediterranean increases, inflow and outflow also in-
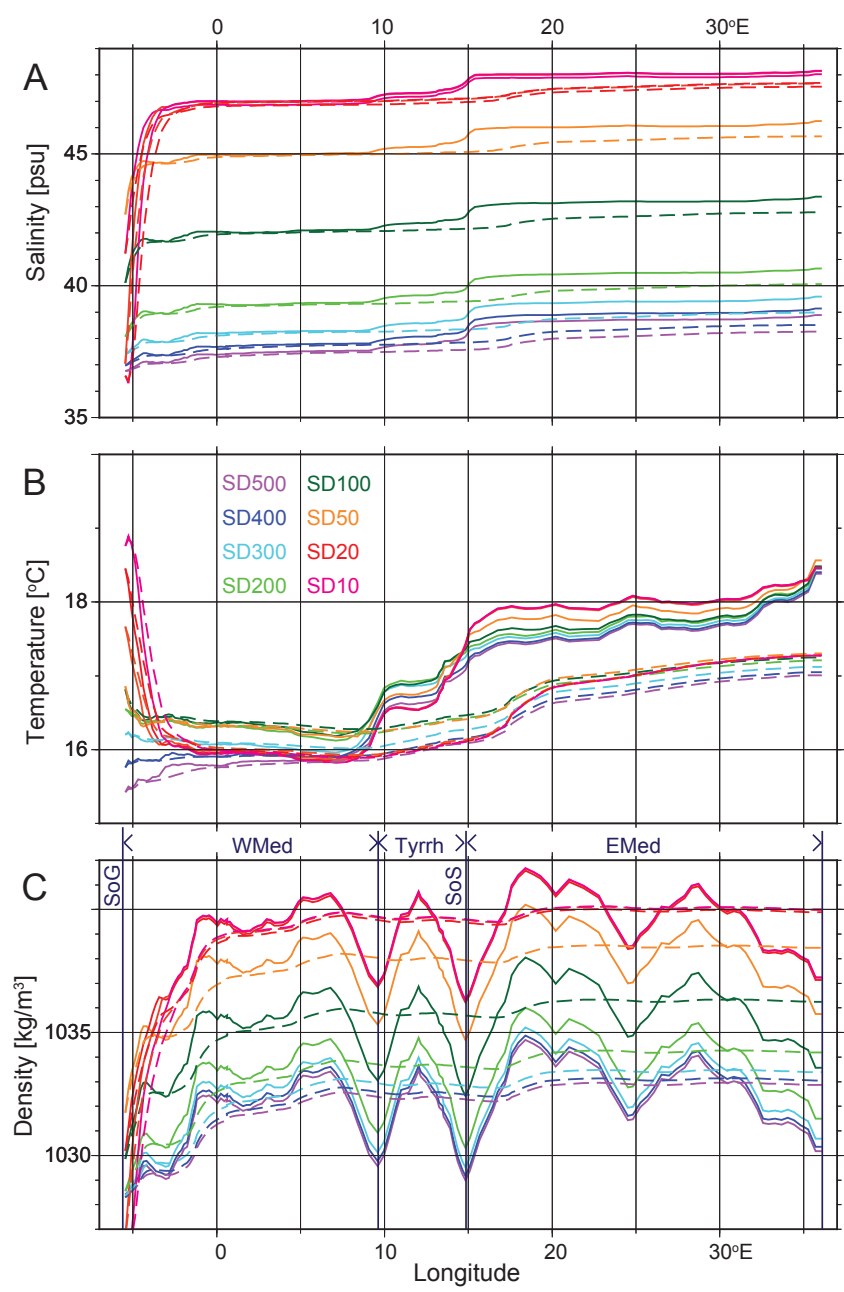

Figure 7. Latitude-depth-averaged profiles of salinity (a), temperature (b) and density (c) for SD500-SD10. Dashed lines indicate the volume-averaged salinity/temperature/density of the volume between the Strait of Gibraltar and the indicated longitude. Therefore, the values at $36^{\circ} \mathrm{E}$ are the averages of the whole basin. Indicated in (c) are the longitudinal ranges corresponding to the western basin (WMed), the Tyrrhenian Sea (Tyrrh), and the eastern basin (EMed) and location of the Strait of Gibraltar (SoG) and Strait of Sicily (SoS).

crease. When a steady state is reached, the inflow volume multiplied with its salinity equals the outflow volume multiplied with its salinity. Before steady state more salt flows in than out, Mediterranean salinity increases, and, consequently, transport increases. The increasing transport reduces the difference between salt volume in inflow and outflow and, hence, the salinity rise slows down towards steady state. After $800 \mathrm{yr}$, all experiments with a sill depth $\geq 100 \mathrm{~m}$ (SD100 SD500) are in equilibrium, i.e. salinity and strait transport have reached a steady state.

The basin averages in Fig. 2 do not show where the differences in salinity and temperature arise between the different experiments. For this purpose, Fig. 7a shows the salin- 
ity averaged over depth and along the curvilinear $\mathrm{j}$ coordinate ("latitude") for every $i$ coordinate. Due to the curvilinear grid, these depth- $j$ slices are not exactly north-south. Latitude-depth-averaged temperature and density are calculated in a similar fashion (Fig. 7b, c). Also shown, in dashed lines, is the average temperature/salinity/density of the basin from the Gibraltar Strait up to each longitude. The temperature/salinity/density at the eastern end $\left(36^{\circ} \mathrm{E}\right)$ is thus the basin-averaged value.

Only where the bathymetry was modified to accommodate a different sill depth, i.e. between -6 to $-2^{\circ} \mathrm{E}$, does the shape of salinity curves differ between SD5-SD500. For a shallower sill depth the whole curve, apart from this westernmost segment, shifts to higher salinities. In each curve, salinity increases in two distinct steps at longitudes corresponding to the western basin-Tyrrhenian Sea connection $\left(9^{\circ} \mathrm{E}\right)$ and the Sicily Strait $\left(15^{\circ} \mathrm{E}\right)$ (Fig. 7c). Although salinities in each basin - western, Tyrrhenian and eastern basin - are higher at shallower sill depths, the difference between them is nearly constant: $\approx 0.4$ between the western basin and the Tyrrhenian, $\approx 0.8$ between the Tyrrhenian and eastern basin. These steps are visible in this representation due to fast changes in the water properties at the gateways, the cumulative average salinity increases more gradually.

Latitude-depth-averaged temperatures in Fig. $7 \mathrm{~b}$ have a large spread near the gateway. Water depths near the gateway are shallower when the sill depth is shallower, hence the influence of warm surface water on the average temperature in this area is larger and the temperature higher. In contrast to the salinity curves, the relative position of the temperature curves is not the same in all subbasins; in the western basin temperatures are relatively low in SD500-SD300 and SD20-SD5, in the eastern basin temperatures increase from SD500 to SD5. Given that surface forcing is constant, these differences must be caused by differences in the circulation which we will elaborate on below. Compared to the steps in the salinity curves, the changes in temperature occur over a broad range of longitudes. Due to the shallow depths near the connections between the basins, the warm surface layer becomes more important for the local average. Notwithstanding local differences, the trend in the basinal averages is towards higher temperatures at shallower sill depths.

The density curves in Fig. 7c illustrate the combined effect of salinity and temperature. Because salinity is fairly stable in each subbasin, density changes in subbasins are caused by temperature differences. Because these temperature differences are mainly caused by different latitudinally averaged water depths, the density curve reflects the average water depth. Shallow low density areas are the connections between the subbasins, the Aegean Sea and the easternmost eastern basin.

The main features of the basinal circulation can be captured in the minimum and maximum strengths of the overturning cells and the depths where these occur in the western and eastern basin. These parameters are shown as a function of sill depth in Fig. 8. The upper cell is consistently deeper and stronger in the western than in the eastern basin (as visible in Fig. 5 for SD300). For the deep cell this pattern is reversed: it is consistently deeper and stronger in the eastern basin than in the western basin. In the experiments that have reached a steady state, i.e. SD100-SD500, the strength and depth of all cells except the upper cell in the western basin are strikingly similar. In SD5-SD50, where a steady state has not yet been reached, the strength of the overturning cells changes significantly between 400 and $800 \mathrm{yr}$ (light and dark symbols, respectively). Over this period, the strengths of the western deep cell and the eastern deep and upper cell in SD5SD200 move towards the steady state value that is reached in SD100-SD500. This suggests that a similar overturning circulation will eventually be reached regardless of the sill depth. A difference not captured in Fig. 8 is the depth of the interface between the upper and deep overturning cells. Even though the depth of the minimum and maximum strength remains the same, the interface shifts to shallower depths when the upper overturning cell loses strength.

Compared to the overturning in steady state, deep overturning in the eastern basin is more vigorous before a steady state is reached. In the western basin deep overturning is weaker before a steady state, as are the surface cells in the western and eastern basin. Towards a steady state, deep water formation in the eastern basin slows down when the vertical density gradient in the basin stabilizes. At the same time, intermediate water formation in both basins and deep water formation in the western basin pick up when vertical temperature differences decrease.

The only cell that stabilizes at a different strength depending on sill depth, is the upper cell in the western basin. The increase in overturning strength from SD100 to SD500 $(+0.84 \mathrm{~Sv})$ is similar to the increase in exchange with the Atlantic (+0.91 Sv, Fig. 9). From this similarity it can be inferred that the upper overturning cell in the western basin is mainly controlled by the exchange with the Atlantic. The temperatures in the western basin are consistent with this: temperatures are lower, i.e. closer to Atlantic values, when the exchange with the Atlantic is larger (SD100 to SD500). SD5-SD20 deviate from this trend (Fig. 7b). However, not being in steady state, the deep water temperature in the western basin is still rising after $800 \mathrm{yr}$ in these experiments.

The temperature in the eastern basin is only affected by the magnitude of the Atlantic-derived inflow in the surface layer near the Strait of Sicily. Therefore, a reduced Atlantic inflow cannot explain the small temperature increase from SD500 to SD100 in the eastern basin (Fig. 7b). This temperature increase is most pronounced below $250 \mathrm{~m}$ and associated with a small change in overturning circulation. The upper and lower cell in the eastern basin are minimally stronger in SD100 compared to SD500. In the reference experiment, deep water was formed where sea surface temperatures were low, and intermediate water where maximum salinities were reached near Cyprus. At higher salinities, the change in den- 

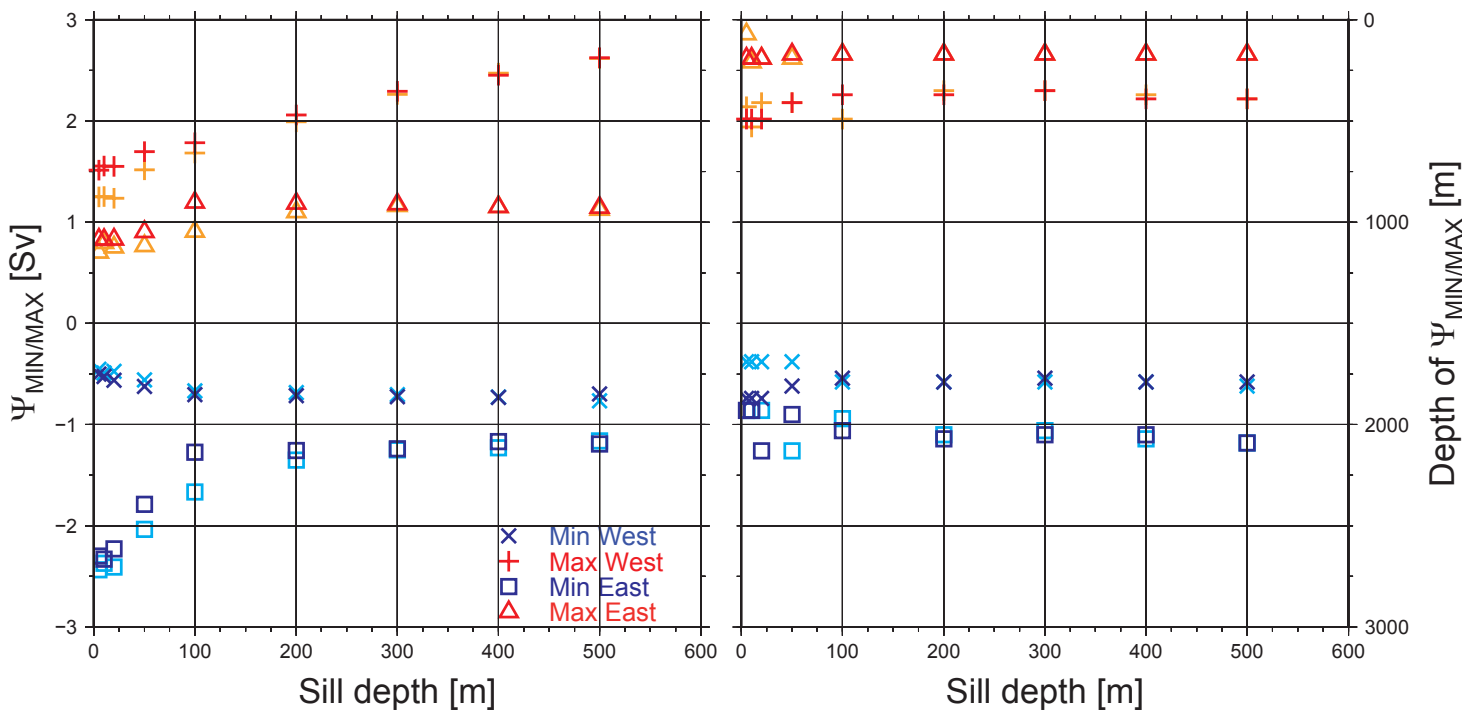

Figure 8. Strength (left) and depth of overturning extrema (right) of the upper (red) and deep (blue) zonal overturning cells in the western and eastern basin. To illustrate temporal changes, light colours indicate the value after $400 \mathrm{yr}$, dark colours the value after $800 \mathrm{yr}$.

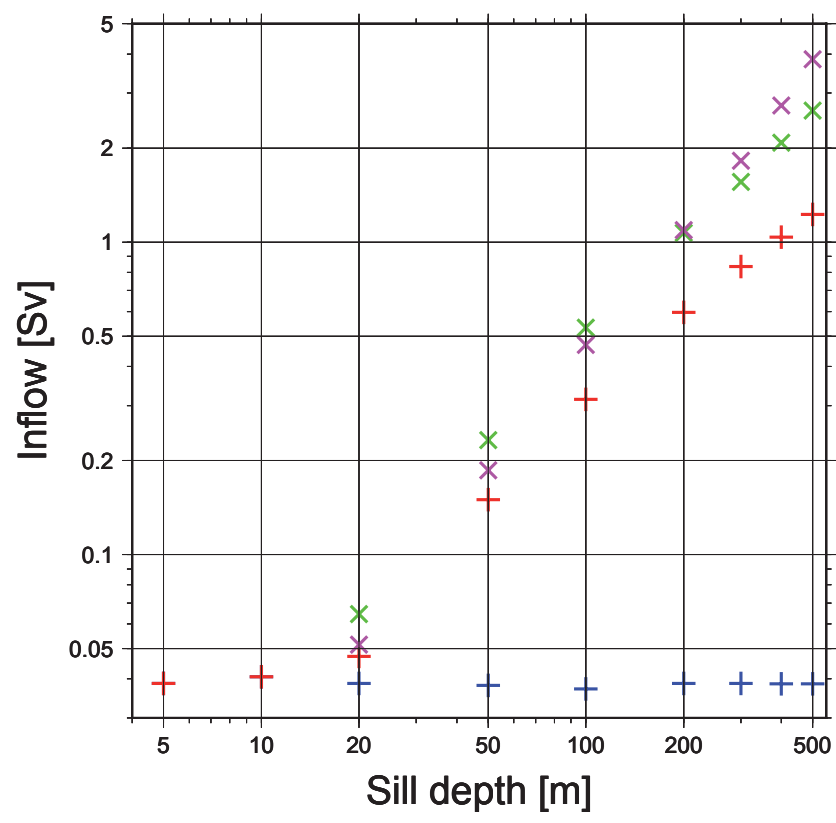

Figure 9. Modelled inflow (red plus signs) and net flow (blue plus signs) in SD500-SD5. Green crosses show the inflow calculated with hydraulic control theory from the basin-averaged densities of the Atlantic and Mediterranean. Purple crosses indicate the inflow calculated with hydraulic control theory using the average density of inflow and outflow in the gateway instead of basin averages.

sity caused by cooling of surface water is comparatively larger. As a consequence, the density of the surface waters increases more due to the same cooling and the mixed layer depth increases significantly throughout the eastern basin. Furthermore, due to the slightly higher sea surface temper- atures at shallower sill depths (Fig. 7b), the relaxation to the annual mean air temperature results in a stronger heat loss, a larger increase in density, and again a deeper mixed layer. Both mechanisms drive a stronger intermediate water formation and slightly enhance the strength of the upper overturning cell. Noteworthy is the appearance of a new branch of intermediate water formation in the northern Ionian Basin in lower sill depth experiments. This area receives less relatively low saline water from the western basin at shallower Atlantic sill depths due to a lower density difference between the basins. Consequently, water becomes dense enough to sink in this area. Compared to the dense water formation sites in the Adriatic and Aegean, surface water is warmer in the Ionian Basin. Due to the reduced vertical density gradient at shallower sill depths, dense water formed in the Adriatic flows downslope to greater depths, thereby enhancing the strength of the deep overturning cell. In summary, lower density gradients at shallow sill depths enhance upper and deep overturning circulation in the eastern basin which leads to the small increase in intermediate and deep water temperatures observed in Fig. 7b.

\subsubsection{Strait transport}

The magnitude of modelled strait transport as a function of sill depth is illustrated in Fig. 9 (red plus signs). Down to a sill depth of $20 \mathrm{~m}$, inflow decreases steadily towards the value of net flow (blue plus signs) which is essentially constant in all runs. Inflow is almost linearly proportional to sill depth; only towards deeper sill depths does the increase in inflow flatten slightly. Outflow is not shown because it shows the same trend as the inflow (outflow being inflow minus net flow). 


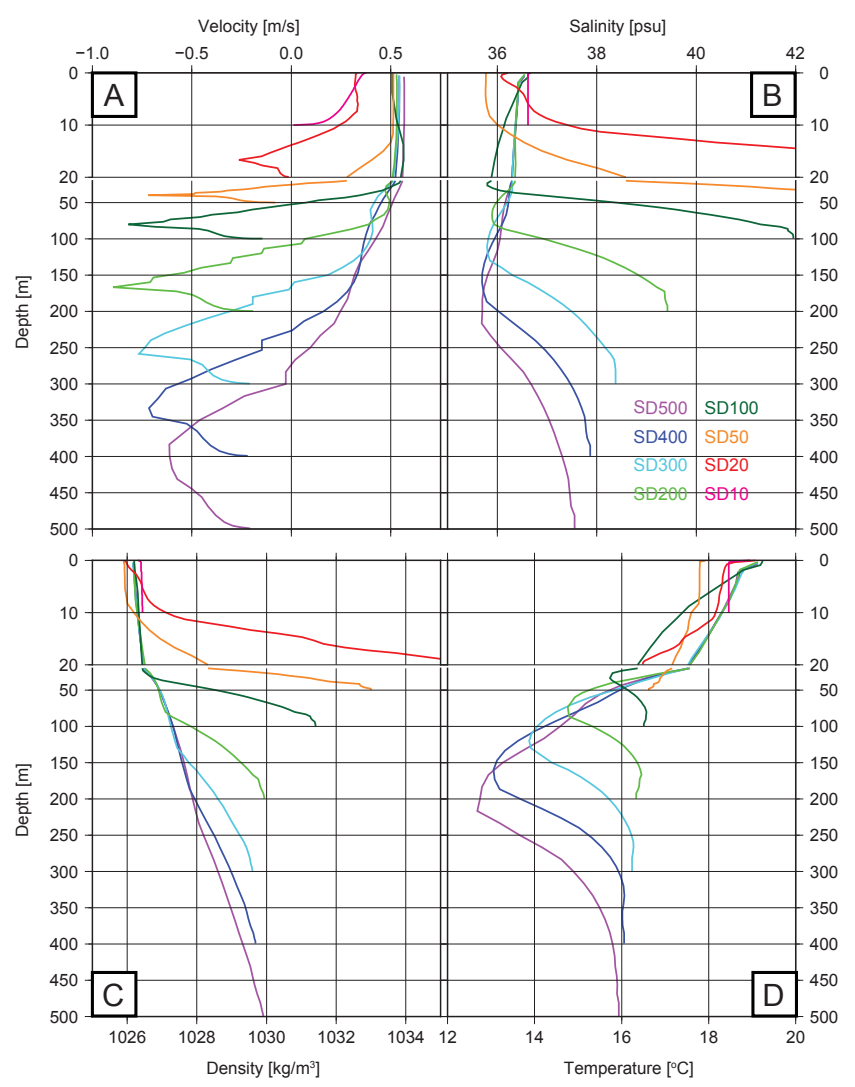

Figure 10. Vertical profiles of zonal velocity (a), salinity (b), density (c) and temperature (d) at the sill in the Strait of Gibraltar in experiments SD500-SD10. Note the change in vertical scale at $20 \mathrm{~m}$. Temperature and salinity profiles of SD50 stand out with incongruent values near the surface. This is caused by a numerical overshoot due to steep slopes near the gateway in this experiment.

Even though the Atlantic-Mediterranean exchange appears to be a simple two-way flow from Fig. 9, velocity, salinity, temperature and density profiles in the gateway show that this is not true (Fig. 10). Velocity (Fig. 10a) is positive in the top layer and decreases gradually towards the interface between inflow and outflow, at a depth lower than half the sill depth, and decreases again towards the bottom due to bottom friction. Salinity (Fig. 10b) in the top layer is near constant at all sill depths, being supplied with Atlantic water with relatively constant salinity. The lower layer becomes increasingly more saline towards shallower sill depths in accordance with the average basinal salinity. Temperatures (Fig. 10d) decrease in the top layer from the surface to the interface depth, and increase again towards the bottom. The high temperatures at the surface are caused by the heat flux at the surface. In the Atlantic, temperatures drop significantly with depth (Fig. 4). In the surface inflow this results in a lower temperature near the interface depth at deeper sill depths. In the Mediterranean, temperatures decrease less with depth. Therefore, temperatures in the outflow move back to higher values away from the interface. The gradual change of ve- locity, temperature and salinity between inflow and outflow indicates mixing between the two layers. The combined effect of salinity and temperature is expressed in the density profiles (Fig. 10). Towards shallower sill depths the density difference between the Atlantic surface flow and Mediterranean outflow becomes larger. i.e. density changes faster over a shorter vertical distance.

In the present day, the Mediterranean is a heat sink for the Atlantic, i.e. the Mediterranean has a net surface heat loss. The present-day net surface heat loss is estimated to be $5 \mathrm{~W} \mathrm{~m}^{-2}$ based on heat transport measurements in the Strait of Gibraltar (Macdonald et al., 1994). Numerical models and reanalyses, however, show a much larger range of estimates, e.g. $-21-40 \mathrm{~W} \mathrm{~m}^{-2}$ (Sanchez-Gomez et al., 2011). Table 2 gives an overview of heat transport through the Strait of Gibraltar for different sill depths. By spreading the net flow at the Strait over the whole Mediterranean surface area, we get the equivalent net surface heat loss (ENSHL) presented in the last column. Even though the absolute value is not exactly reproduced, the sign of the Mediterranean heat budget is correct in the reference experiment. Heat inflow and outflow both decrease almost linearly towards shallower sill depths, until at $10 \mathrm{~m}$ the outflow stops. The net flow is small compared to the inflow and outflow and increases to an almost constant value of $3 \mathrm{TW}$ at sills shallower than $200 \mathrm{~m}$. Only in SD500 is the inflow from the Atlantic cold enough at depth, in combination with a warm outflow, to cause a net heat flow from the Mediterranean to the Atlantic. In all other experiments the Atlantic inflow is dominated by surface waters significantly warmer than the outflow.

As noted in Fig. 10, the basin-averaged temperature is higher when the sill is shallower. This is counterintuitive since one would expect the surface heat loss to dominate over the smaller Atlantic inflow and make Mediterranean temperatures drop. However, the Atlantic inflow becomes increasingly warmer at shallower sill depths because a larger portion of the inflow is drawn from the warm Atlantic surface layer. Surface temperatures in the Mediterranean are only notably affected by the Atlantic inflow temperature in SD500 and SD400, in all other experiments surface temperatures and hence the net surface heat loss are similar. Because the warmer Atlantic inflow is not compensated for by a larger surface heat loss, the Mediterranean warms up until the outflow is warm enough to compensate for the warmer inflow and the Mediterranean heat budget is back to zero.

In SD5 and SD10, the inflow is constant and equal to the net flow, i.e. there is no outflow. Although outflow is blocked in these two experiments, neither experiment has reached a steady state yet. Salinity rises constantly at $11.6 \mathrm{psu} \mathrm{kyr}^{-1}$ as long as outflow is blocked because all salt that enters the Mediterranean through inflow $\left(4.3 \times 10^{13} \mathrm{~kg} \mathrm{yr}^{-1}\right)$ is retained in the Mediterranean. In SD20 and SD50, like SD5 and SD10 not yet in steady state, the ongoing salinity rise in the Mediterranean is accompanied by a steady increase in the outflow and, hence, inflow. It is possible that the increas- 
Table 2. Overview of heat transport through the Strait of Gibraltar. ENSHL: equivalent net surface heat loss.

\begin{tabular}{lcccc}
\hline Sill depth (m) & Inflow (TW) & Outflow (TW) & Net flow (TW) & ENSHL $\left(\mathrm{W} \mathrm{m}^{-2}\right)$ \\
\hline 500 & 73.604 & 74.108 & -0.504 & -0.212 \\
400 & 63.121 & 62.326 & 0.795 & 0.334 \\
300 & 52.984 & 50.583 & 2.401 & 1.010 \\
200 & 39.231 & 36.028 & 3.204 & 1.348 \\
100 & 21.241 & 18.142 & 3.099 & 1.304 \\
50 & 10.542 & 7.563 & 2.980 & 1.253 \\
20 & 3.487 & 0.607 & 2.880 & 1.212 \\
10 & 3.035 & 0.000 & 3.035 & 1.277 \\
\hline
\end{tabular}

ing density difference between Mediterranean and Atlantic in SD10 and SD5 will eventually incite two-way flow. However, the anticipated salinities for the steady states in these experiments are $>100 \mathrm{psu}$, which will take at least another $5000 \mathrm{yr}$ to be reached. Therefore, due to the additional model run time required, reaching steady states in SD5 and SD10 is unfeasible in the current model setup. Moreover, the equation of state - which relates temperature, salinity and pressure to density - is only valid up to 42 psu. At higher salinities, a linear extrapolation is used to calculate the density increase due to salinity. This will give an increasingly larger error in the density determination towards higher salinities. Also, the viscosity of water will change significantly at such high salinities, a process not included in the model.

In summary, exchange between the Mediterranean and Atlantic is proportional to the sill depth until at $10 \mathrm{~m}$ sill depth outflow is blocked and only inflow remains. The interface between inflow and outflow is consistently deeper than half the sill depth. The highest velocities are reached in the saline, warm Mediterranean outflow which is overlain by a less saline, colder Atlantic inflow.

\section{Discussion}

\subsection{Constant forcing}

Even though the usage of a minimal constant forcing is a deliberate choice in our model setup, it may cause changes in the Mediterranean circulation and water characteristics compared to a model with a non-constant (seasonal) forcing. Whereas most deep water formation would be episodic, i.e. concentrated in the winter months, with a seasonal cycle, a constant forcing drives a constant deep water formation. Deep water forms year-round in the northern part of the western and eastern basins due to cooling at the surface, i.e. a net surface heat loss of $1.3 \mathrm{~W} \mathrm{~m}^{-2}$ (Table 2). This cooling is not the strong winter cooling $\left(5 \mathrm{~W} \mathrm{~m}^{-2}\right)$ that would occur with a seasonal forcing, hence deep water is formed at relatively high temperatures. The deep basin is filled with warm saline water which is, on average, $3.4^{\circ} \mathrm{C}$ warmer than observed in the present-day Mediterranean (Fig. 4). The depth of deep water formation (Fig. 6) and also the rate are, however, not significantly affected by the constant forcing because deep basinal water and dense water formed at deep water formation sites are both warmer and their respective densities both change with a similar amount. Furthermore, the deep water formation sites are at or close to the actual observed locations because the overall circulation, including the transport of preconditioned water to the deep water formation sites, and the buoyancy forcing are reproduced to an acceptable degree. Mediterranean salinity is relatively constant throughout the year in the present day and is not significantly affected by the use of a constant forcing.

Strait transport is not significantly affected by the high deep water temperatures and associated warm Mediterranean outflow. A change in salinity affects density, and therefore Mediterranean outflow, four times more than temperature, i.e. a change of $1 \mathrm{gL}^{-1}$ has the same impact on density as $4{ }^{\circ} \mathrm{C}$. Mediterranean outflow in a model forced with a seasonal cycle would be slightly stronger due to lower intermediate/deep water temperatures in the Mediterranean and the associated increase in the density contrast with the Atlantic. Also, the amount of heat lost through Mediterranean outflow would be lower because a larger part of the heat from the Atlantic inflow is lost at the surface instead.

In summary, although the constant forcing results in yearround formation of relatively warm deep water, the overall circulation, deep water formation, strait transport, and salinity are sufficiently reproduced to study the impact of sill depth on them.

\subsection{Hydraulic control}

A comparison of exchange in the model and that predicted by hydraulic control theory is called for since hydraulic control theory has been extensively used to describe the AtlanticMediterranean exchange. Hydraulic control theory can be used to calculate the flow through a narrow strait if the geometry and density difference along the strait are known. A recent overview of the basic principles underlying hydraulic control theory and an application to the Mediterranean can be found in Meijer (2012). Differences between exchange calculated with hydraulic control theory and that from the 
model are to be expected due to the more complex physics in the model. For comparison with the modelled exchange, an expression for hydraulic control for a strait with a rectangular cross section and zero net flow is used (Farmer and Armi, 1986; Bryden and Kinder, 1991):

$Q_{\mathrm{A}}=Q_{\mathrm{M}}=0.208 \cdot \sqrt{g^{\prime} H} H W$,

where $Q_{\mathrm{A}}$ is the inflow from the Atlantic which is equal to the outflow from the Mediterranean, $Q_{\mathrm{M}} ; H$ is the sill depth, $W$ the strait width, and the reduced gravity, $g^{\prime}$, is defined by

$g^{\prime}=g\left(\rho_{\mathbf{M}}-\rho_{\mathrm{A}}\right) / \rho_{\mathbf{M}}$,

where $g$ is the gravitational acceleration, $\rho_{\mathrm{M}}$ the Mediterranean outflow water density and $\rho_{\mathrm{A}}$ Atlantic water density.

Besides the modelled strait transport, Fig. 9 also shows the inflow calculated with Eq. (1) for a strait with the same dimensions (width and depth) as in the model; Atlantic and Mediterranean basin-averaged densities are used as $\rho_{\mathrm{A}}$ and $\rho_{\mathrm{M}}$ respectively. Compared to the strait transport predicted by hydraulic control, the modelled transports are consistently lower. The absolute difference as well as the ratio between inflow predicted by hydraulic control and inflow from the model decrease towards shallower sill depths, i.e. modelled transport is closer to that predicted by hydraulic control in shallow gateways.

In hydraulic control theory, the velocity and density profiles at the gateway are envisaged to be a step function with a constant positive velocity and low density in the upper layer and a constant negative velocity and high density in the bottom layer. In contrast, profiles derived from the model (Fig. 10) show a gradual change in water properties near the interface between inflow and outflow. It must be noted, however, that density and salinity profiles at shallow sill depths are closer to a step function than those at deep sill depths; a larger change in salinity/density occurs in a smaller depth interval. This may partly explain why hydraulic control theory better matches modelled transports at shallower sill depths.

When transport is calculated by inserting the average density of inflow and outflow in Eq. (1), instead of averages of Atlantic and Mediterranean basins, it is closer to modelled values at shallow sill depths and further from modelled values at deep sill depths. The density difference between inflow and outflow is larger than between the basin averages at deep sill depths, while it is smaller for shallower sill depths. At sill depths $>100 \mathrm{~m}$, mixing between the inflow and outflow reduces the temperature of the outflow, which is already more saline than the inflow, and lowers the density. Hence, the density contrast between inflow and outflow is increased compared to the difference between the basin averages. Consequently, the inflow predicted by hydraulic control with the densities in the gateway is higher than that with basin average densities. At sill depths $<100 \mathrm{~m}$, the density difference between the inflow and outflow is smaller than the difference between basin averages because the largest difference in temperature between the basins occurs at greater depths than those involved in the exchange. Accordingly, the inflow predicted by hydraulic control with densities in the gateway is lower than that from basin-averaged densities and closer to modelled transports.

Regardless of the densities used, exchange calculated with hydraulic control theory is always larger than modelled transport. The aforementioned vertical mixing between inflow and outflow is one obvious cause of the difference. Another important factor is friction; at the bottom it slows down the outflow and friction between the inflow and outflow slows down both. The Coriolis force does not play a role here due to the narrow width of the gateway.

In summary, transport at shallow sill depths is closer to that predicted by hydraulic exchange theory than at deep sill depths because mixing between inflow and outflow is not as effective in reducing the difference between them. Furthermore, using basin-averaged density differences for calculation of the exchange with hydraulic control gives an overestimation of the exchange because water characteristics at the depths involved in the exchange are not representative of the whole basin.

\subsection{The role of sill depth}

In experiments with sill depths in the range of $500-5 \mathrm{~m}$, basin-averaged salinities and temperatures are consistently higher at shallower sill depths. Spatial differences, e.g. between the western and eastern basin, are largely independent of sill depth. The upper overturning cell in the western basin is controlled by the exchange with the Atlantic and is weaker at shallower sill depths. The upper overturning cell in the eastern basin and the deep overturning cells in both basins, however, are practically constant in depth and strength at all sill depths as soon as a steady state has been reached. Dense water formation is slightly more temperature-driven when basin averaged salinities are higher; at high salinities surface cooling causes a larger increase of density than at low salinities. However, overall, the locations and rate of dense water formation change little.

The influence of sill depth on circulation and water characteristics found in this study is, mainly due to differences in model setup, different from that found by Alhammoud et al. (2010) (AMD10). In AMD10, a highly idealized representation of the Mediterranean was used, which consists of a single large basin with a depth of $1500 \mathrm{~m}$ gradually shallowing towards the margins. In accordance with our findings for the western basin they found a steadily increasing inflow and stronger upper zonal overturning cell in experiments with increasingly larger sill depths. Their deep overturning cell, however, almost disappears at large sill depths whereas it is here found to be constant in strength regardless of sill depth. The shift of the interface between upper and deep overturning cells in their experiments does resemble the shift found here. Because their basin extends to only $1500 \mathrm{~m}$, the deep 
overturning cell is suppressed by stronger surface cells when these extend to greater depths, while it persists below $1500 \mathrm{~m}$ in our experiments. As in our experiments, deep water circulation, although strongly reduced, never entirely stopped in the experiments of AMD10.

The low resolution used in AMD10 resulted in a $222 \mathrm{~km}$ wide Strait of Gibraltar. Due to this width, exchange with the Atlantic was found to be consistent with rotational control on the flow instead of hydraulic control. The width of the Strait of Gibraltar in our model $(13 \mathrm{~km})$ is well below the Rossby radius and, hence, rules out rotational control. The larger strait transports in AMD10 kept Mediterranean salinities closer to Atlantic values, but the overall trend towards higher salinities at lower sill depths is consistent with our findings.

\subsection{The interpretation of the Late Miocene sedimentary record}

As argued in the introduction, we expect that the change in circulation and water properties due to variation in sill depth that we calculated for a basin with the shape of the present Mediterranean forms a starting point for understanding the past as well. In this section we relate our findings to the Late Miocene sedimentary record.

Stable isotopes and faunal changes in the pre-MSC interval of the Late Miocene suggest that in an interval with increasing salinity, the average deep water oxygenation decreased steadily (Kouwenhoven and van der Zwaan, 2006). As already noted by Kouwenhoven and van der Zwaan (2006) and Krijgsman et al. (2000), the occurrence of sapropels in this interval indicates precessional variation of the oxygenation of Mediterranean deep water on top of the longterm trend. The estimated depth of the marginal basins in which the Monte del Casino, Metochia, Faneromeni and Gibliscemi sections accumulated is $300-1200 \mathrm{~m}$. In these basins the decreasing oxygenation and sapropelic sedimentation are observed. All are located in the eastern Mediterranean basin in which, in our model, the upper overturning cell is less than $500 \mathrm{~m}$ deep. If rates of deep water formation and the strength of deep overturning are lower at shallower sill depths, oxygen conditions in the deep water layer would decrease concomitant with a decreasing gateway depth. Model results, however, do not show a significant change in either deep water formation or deep overturning in the eastern basin.

In the western basin, depths up to $1200 \mathrm{~m}$ are in the upper overturning cell in SD500-SD100. Oxygenation of the marginal basins in this setting would not be by deep water formation, but by intermediate water formation in the upper overturning cell. The simultaneous decrease of exchange with the Atlantic and strength of the upper overturning cell in the western basin towards shallower sill depths leads to a longer residence time of the water in the upper cell of the western basin. Consequently, water in the marginal basins will be replenished more slowly with oxygenated water from the surface. Therefore, model results from the western basin could explain the suggested correlation between sill depth and oxygenation. Because AMD10 represents the Mediterranean with only one basin, their correlation between observations and model results is similar to what is suggested here for the western basin.

Model results thus seem to contradict the notion that restriction of the Atlantic-Mediterranean gateway induces lower oxygenation of deep water in the eastern basin. A lower oxygenation may, however, be inferred for the upper overturning cell in the western basin. Due to the relatively shallow connection between the western and eastern basin, only the western overturning is affected by sill depth in a way that seems consistent with the data. A possible cause of the discrepancy between model results and observations is the present-day bathymetry used in the model. If the connection between both basins was deeper in the Late Miocene, the upper overturning cell could have extended further and deeper into the eastern basin. Without the Sicily Strait, model results are expected to be similar to those in AMD10 who indeed had a single surface overturning cell in the whole Mediterranean.

In the present day, deep water formation is mainly driven by cooling of surface water during the winter. Despite the fact that deep water formation in the model is continuous, the forcing that drives deep water formation is the same. We therefore argue that deep water formation is sufficiently represented in our setup to reproduce possible changes in deep water oxygenation that may occur in a less idealized case.

Another simplification in the surface forcing, on the other hand, may influence the correlation of model results and observations: the inclusion of river discharge in a uniform surface flux equal to E-P-R. Increased river discharge during precession minima is generally accepted to be an important factor in the establishment of low-oxygen conditions during sapropel formation. River discharge is thought to form a fresh-water-lid at the surface, hindering deep water formation by reducing surface layer densities. Due to mixing with more saline water and evaporative concentration, water originating from rivers will lose its fresh water signature when it moves away from the outlet. If the receiving basin is at higher salinity, the density difference between river water and the basin is larger and stratification will be stronger. Although depending on the volume and location of river input, basin circulation, evaporation - precipitation, and the rate of mixing with surrounding water, we can assume that stratification due to river discharge is stronger when the basinaveraged salinity is higher. Hence, deep water formation may be more effectively reduced at lower sill depth. If a river drains into a marginal basin with restricted exchange with the deep basin, stratification is presumably more severe and deep water oxygenation even more strongly reduced.

A spatially heterogeneous distribution of precipitation may have the same effect as river discharge. Precipitation, however, does not give a continuous fresh water input at the 
same location like river input. Hence, its influence with respect to river discharge is expected to be lower.

\subsection{Blocked outflow}

Notwithstanding the fact that SD10 and SD5 are not yet in steady state, it is the first time that a blocked outflow has been observed in an ocean circulation model in this context. From hydraulic control theory, one layer flow is predicted to occur only when the sill depth is a few metres for a gateway with a width of $13 \mathrm{~km}$ (Meijer, 2012). If bottom friction is taken into account, this depth is expected to be somewhat deeper. Because the density difference between the Atlantic and Mediterranean is still rising at the time model results are shown for, it may be that outflow will commence if the experiment is run to steady state.

Our model results suggest that if a sill depth of $\approx 10 \mathrm{~m}$ existed during the MSC, either due to a global sea level drop or local uplift due to flexure or tectonics, the salinity rise in the Mediterranean would be maximal. Consequently, the salt gain of the Mediterranean is highest in this scenario, allowing for the fast accumulation of evaporites. During blocked outflow, $15 \mathrm{~km}^{3}$ of halite is transported to the Mediterranean every year. At this rate it would take $33-133 \mathrm{kyr}$ to form the $0.5-2$ million $\mathrm{km}^{3}$ of halite observed on seismics (Ryan, 2008). Halite formation in the deep Mediterranean basins took place during an $60 \mathrm{kyr}$ interval which encompasses two glacials: 5.61-5.55 Ma with glacials TG12 and TG14. The growth of icecaps on the poles during this interval would reduce global sea level, lowering the relative sill depth. Furthermore, glacials are characterized by a relatively high fresh water deficit in the Mediterranean due to reduced river discharge and precipitation. In this situation, salinity rise and salt gain will be even higher than found in our model. During blocked outflow, inflow could thus bring in the observed volume of salt in the $60 \mathrm{kyr}$ MSC interval. The blocked-outflow scenario is therefore plausible. To examine whether blockedoutflow endures at higher density contrasts, a model should be set up to represent only the Strait of Gibraltar, or another gateway thought to be open during the Messinian. This, however, is impossible with the current model because the equation of state implemented in POM is not valid at salinities larger than 42 psu and anticipated viscosity changes at high salinities cannot be dealt with.

\section{Conclusions}

In this study, a parallel version of POM (sbPOM) has been used to examine changes in Mediterranean circulation and water characteristics due to restriction of the Atlantic connection. Model results have implications for the interpretation of the Late Miocene sedimentary record in the Mediterranean. Compared to earlier models of the (Miocene) Mediterranean, the use of a curvilinear grid and parallel code allows for the use of a higher resolution and more realistic bathymetry even in long model runs ( $800 \mathrm{yr}$ ). A comparison of the results from our model with observations of the present day shows that, despite an idealized and constant surface forcing, Mediterranean circulation and water properties are generally well reproduced.

The model setup presented in this study would seem to provide a valuable basis and reference for examination of additional aspects of Mediterranean palaeoconfigurations. This may relate to other aspects of the Miocene evolution, for example, but our setup is also applicable to the Last Glacial Maximum when lower sea level was responsible for a reduction in sill depth.

The main results and implications for the Late Miocene Mediterranean are the following:

- Basin-averaged salinity, temperature and density increase when the sill is shallower. However, spatial distribution and inter-basinal differences in water properties in the Mediterranean are largely unaffected by sill depth.

- The strength of the upper overturning cell in the western Mediterranean is proportional to the magnitude of water exchange with the Atlantic. Overturning in the eastern basin is not significantly affected by the depth of the sill.

- Temperature-driven dense water formation operates regardless of the basin-averaged salinity. At shallower sill depths, the higher salinity in the Mediterranean results in a stronger salinity-driven dense water formation in the eastern basin.

- Modelled strait transport is always smaller than that predicted by hydraulic control theory. This difference is due to friction, vertical mixing and a difference between basin-averaged density and the density of the water involved in the exchange with the Atlantic.

- Outflow is blocked in (at least the first $800 \mathrm{yr}$ of) experiments with sill depths $\leq 10 \mathrm{~m}$. Future work is needed to establish whether blocked-outflow is a viable scenario for the interval with halite deposition in the MSC.

- With the present-day bathymetry, restriction of the Atlantic-Mediterranean connection does not significantly alter Mediterranean deep water circulation and refreshening. Hence, model results do not affirm the hypothesis that deep water ventilation decreases at shallower sill depths.

Acknowledgements. The authors would like to thank Rinus Wortel for valuable input on drafts of this article. The manuscript benefited from reviews by two anonymous reviewers and Mike Rogerson. R. P. M. Topper was supported by the Netherlands Research Center for Integrated Solid Earth Science. Computational resources for 
this work were also provided by ISES (ISES 3.2.5 High End Scientific Computation Resources). Figures in this paper were created using GMT version 4.5.1 (Wessel and Smith, 1991).

Edited by: U. Mikolajewicz

\section{References}

Adloff, F., Mikolajewicz, U., Kuc(era, M., Grimm, R., MaierReimer, E., Schmiedl, G., and Emeis, K.-C.: Upper ocean climate of the Eastern Mediterranean Sea during the Holocene Insolation Maximum - a model study, Clim. Past, 7, 1103-1122, doi:10.5194/cp-7-1103-2011, 2011.

Ahumada, M. A. and Cruzado, A.: Modeling of the circulation in the Northwestern Mediterranean Sea with the Princeton Ocean Model, Ocean Sci., 3, 77-89, doi:10.5194/os-3-77-2007, 2007.

Alhammoud, B., Meijer, P. Th., and Dijkstra, H. A.: Sensitivity of Mediterranean thermohaline circulation to gateway depth: A model investigation, Paleoceanography, 25, PA2220, doi:10.1029/2009PA001823, 2010.

Amante, C. and Eakins, B. W.: ETOPO1 1 arc-minute global relief model: procedures, data sources and analysis, NOAA Technical Memorandum NESDIS NGDC-24, 19 pp., 2009.

Antonov, J. I., Levitus, S., Boyer, T. P., Conkright, M. E., and O'Brien and C. Stephens, T. D.: World Ocean Atlas Data 1998, NOAA Atlas NESDIS, 27, 166 pp., 1998.

Astraldi, M., Balopoulos, S., Candela, J., Font, J., Gacic, M., Gasparini, G. P., Manca, B., Theocharis, A., and Tintoré, J.: The role of straits and channels in understanding the characteristics of Mediterranean circulation, Prog. Oceanogr., 44, 65-108, 1999.

Beckers, J.-M., Rixen, M., Brasseur, P., Brankart, J.-M., Elmoussaoui, A., Crépon, M., Herbaut, Ch., Martel, F., Van den Berghe, F., Mortier, L., Lascaratos, A., Drakopoulos, P., Korres, G., Nittis, K., Pinardi, N., Masetti, E., Castellari, S., Carini, P., Tintore, J., Alvarez, A., Monserrat, S., Parrilla, D., Vautard, R., and Speich, S.: Model intercomparison in the Mediterranean: MEDMEX simulations of the seasonal cycle, J. Marine Syst., 33, 215-251, 2002.

Benson, R. H., Bied, K. R.-E., and Bonaduce, G.: An important current reversal (influx) in the Rifian corridor (Morocco) at the Tortonian-Messinian boundary: the end of the Tethys ocean, Paleoceanography, 6, 164-192, 1991.

Berntsen, J. and Oey, L.-Y.: Estimation of the internal pressure gradient in $\sigma$-coordinate ocean models: comparison of second, fourth-, and sixth-order schemes, Oc. Dynam., 60, 317-330, 2010.

Bertini, A.: The Northern Apennines palynological record as a contribute for the reconstruction of the Messinian palaeoenvironments, Sediment. Geol., 188-189, 235-258, 2006.

Betzler, C., Braga, J. C., Martín, J. M., Sánchez-Almazo, I. M., and Lindhorst, S.: Closure of a seaway: stratigraphic record and facies (Guadix basin, Southern Spain), Internat. J. Earth Sci., 95, 903-910, 2006.

Blumberg, A. F. and Mellor, G. L.: A description of a threedimensional coastal ocean circulation model, Coast. Estuar. Sci., 4, 1-16, 1987.

Bryden, H. L. and Kinder, T. H.: Steady two-layer exchange through the Strait of Gibraltar, Deep-Sea Res., 38, S445-S463, 1991.
Bryden, H. L. and Stommel, H. M.: Limiting processes that determine basic features of the circulation in the Mediterranean Sea, Oceanol. Ac., 7, 289-296, 1984.

Bryden, H. L., Candela, J., and Kinder, T. H.: Exchange through the Strait of Gibraltar, Prog. Oceanogr., 33, 201-248, 1994.

Candela, J.: The Gibraltar Strait and its role in the dynamics of the Mediterranean Sea, Dynam. Atmos. Oc., 15, 267-299, 1991.

Candela, J.: Mediterranean water and global circulation, vol. 77 of International Geophysics, chap. 5.7, Academic Press, San Diego, 419-429, 2001.

Cramp, A. and O'Sullivan, G.: Neogene sapropels in the Mediterranean: a review, Mar. Geol., 153, 11-28, 1999.

de la Vara, A., Meijer, P. Th., and Wortel, M. J. R.: Model study of the circulation in the Miocene Mediterranean Sea and Paratethys: closure of the Indian gateway, Clim. Past Discuss., 9, 4385-4424, doi:10.5194/cpd-9-4385-2013, 2013.

Dercourt, J., Gaetani, M., Vrielynck, B., Barrier, E., Biju-Duval, B., Brunet, M. F., Cadet, J. P., Crasquin, S., and Sandulescu, M. (Eds.): Peri-Tethys palaeogeographical atlas, CCGM/CGMW, 2000.

Dijkstra, H. A.: Scaling of the Atlantic meridional overturning circulation in a global ocean model, Tellus, 60A, 749-760, 2008.

Drakopoulos, P. G. and Lascaratos, A.: Modelling the Mediterranean Sea: climatological forcing, J. Mar. Syst., 20, 157-173, 1999.

Duggen, S., Hoernle, K., van den Bogaard, P., Rüpke, L., and Phipps Morgan, J.: Deep roots of the Messinian salinity crisis, Nature, 422, 602-606, 2003.

Ezer, T. and Mellor, G. L.: Simulations of the Atlantic Ocean with a free surface sigma coordinate ocean model, J. Geophys. Res., 102, 15647-15657, 1997.

Farmer, D. M. and Armi, L.: Maximal two-layer exchange over a sill and through the combination of a sill and contraction with barotropic flow, J. Fluid Mechan., 164, 53-76, 1986.

Fauquette, S., Suc, J.-P., Bertini, A., Popescu, S.-M., Warny, S., Bachiri Taoufiq, N., Perez Villa, M.-J., Chikhi, H., Feddi, N., Subally, D., Clauzon, G., and Ferrier, J.: How much did climate force the Messinian salinity crisis? Quantified climatic conditions from pollen records in the Mediterranean region, Palaeogeogr. Palaeoclimatol. Palaeocol., 238, 281-301, 2006.

Gennari, R., Manzi, V., Angeletti, L., Bertini, A., Biffi, U., Ceregato, A., Costanza, C., Gliozzi, E., Lugli, S., Menichetti, E., Rosso, A., Roveri, M., and Taviani, M.: A shallow water record of the onset of the Messinian salinity crisis in the Adriatic foredeep (Legnagnone section, Northern Apennines), Palaeogeogr. Palaeoclimatol. Palaeoecol., 386, 145-164, 2013.

Gladstone, R., Flecker, R., Valdes, P., Lunt, D., and Markwick, P.: The Mediterranean hydrologic budget from a Late Miocene global climate simulation, Palaeogeogr. Palaeoclimatol. Palaeocol., 251, 254-267, 2007.

Govers, R.: Choking the Mediterranean to dehydration: The Messinian salinity crisis, Geology, 37, 167-170, 2009.

Hilgen, F. J., Krijgsman, W., Langereis, C. G., Lourens, L. J., Santarelli, A., and Zachariasse, W. J.: Extending the astronomical (polarity) time scale into the Miocene, Earth Planet. Sci. Lett., 136, 495-510, 1995.

Hopkins, T. S.: The thermohaline forcing of the Gibraltar exchange, J. Mar. Syst., 20, 1-31, 1999. 
Hüsing, S. K., Oms, O., Agustí, J., Garcés, M., Kouwenhoven, T. J., Krijgsman, W., and Zachariasse, W.-J.: On the late Miocene closure of the Mediterranean-Atlantic gateway through the Guadix basin (southern Spain), Palaeogeogr. Palaeoclimatol. Palaeocol., 291, 167-179, 2010.

Iovino, D., Straneo, F., and Spall, M. A.: On the effect of a sill on dense water formation in a marginal sea, J. Mar. Res., 66, 325345, 2008.

Ivanovic, R. F., Flecker, R., Gutjahr, M., and Valdes, P. J.: First $\mathrm{Nd}$ isotope record of Mediterranean-Atlantic water exchange through the Moroccan Rifian Corridor during the Messinian Salinity Crisis, Earth Planet. Sci. Lett., 368, 163-174, 2013.

Jordi, A. and Wang, D.-P.: sbPOM: A parallel implementation of Princenton Ocean Model, Environ. Modell. Software, 38, 59-61, 2012.

Jungclaus, J. H. and Mellor, G. L.: A three-dimensional model study of the Mediterranean outflow, J. Marine Syst., 24, 41-66, 2000.

Karami, M. P., De Leeuw, A., Krijgsman, W., Meijer, P. Th., and Wortel, M. J. R.: The role of gateways in the evolution of temperature and salinity of semi-enclosed basins: An oceanic box model for the Miocene Mediterranean Sea and Paratethys, Glob. Planet. Change, 79, 73-88, 2011.

Kouwenhoven, T. J. and van der Zwaan, G. J.: A reconstruction of late Miocene Mediterranean circulation patterns using benthic foraminifera, Palaeogeogr. Palaeoclimatol. Palaeocol., 238, 373$385,2006$.

Kouwenhoven, T. J., Hilgen, F. J., and van der Zwaan, G. J.: Late Tortonian-early Messinian stepwise disruption of the Mediterranean-Atlantic connections: constraints from benthic foraminiferal and geochemical data, Palaeogeogr. Palaeoclimatol. Palaeocol., 198, 303-319, 2003.

Krijgsman, W. and Meijer, P. Th.: Depositional environments of the Mediterranenan "Lower Evaporites" of the Messinian salinity crisis: Constraints from quantitative analysis, Mar. Geol., 253, 73-81, 2008.

Krijgsman, W., Hilgen, F. J., Raffi, I., Sierro, F. J., and Wilson, D. S.: Chronology, causes and progression of the Messinian Salinity Crisis, Nature, 400, 652-655, 1999a.

Krijgsman, W., Langereis, C. G., Zachariasse, W. J., Boccaletti, M., Moratti, G., Gelati, R., Iaccarino, S., Papani, G., and Villa, G.: Late Neogene evolution of the Taza-Guercif Basin (Rifian Corridor, Morocco) and implications for the Messinian salinity crisis, Mar. Geol., 153, 147-160, 1999b.

Krijgsman, W., Garcés, M., Agustí, J., Raffi, I., Taberner, C., and Zachariasse, W. J.: The "Tortonian salinity crisis" of the eastern Betics (Spain), Earth Planet. Sci. Lett., 181, 497-511, 2000.

Lascaratos, A. and Nittis, K.: A high-resolution three-dimensional numerical study of intermediate water formation in the Levantine Sea, J. Geophys. Res., 103, 18497-18511, 1998.

Lascaratos, A., Roether, W., Nittis, K., and Klein, B.: Recent changes in deep water formation and spreading in the eastern Mediterranean Sea: a review, Progress in oceanography, 44, 536, 1999.

Macdonald, A. M., Candela, J., and Bryden, H. L.: An estimate of the net heat transport through the Strait of Gibraltar, in: Seasonal and interannual variability of the Western Mediterranean Sea, edited by: Viollette, P. E. L., 13-32, Am. Geophys. Union, Washington DC, 13-32, 1994.
Mariotti, A., Struglia, M. V., Zeng, N., and Lau, K.-M.: The hydrological cycle in the Mediterranean region and implications for the water budget of the Mediterranean Sea, J. Climate, 15, 16741690, 2002.

Martín, J. M., Braga, J. C., Aguirre, J., and Puga-Bernabéu, A.: History and evolution of the North-Betic Strait (Prebetic Zone, Betic Cordillera): A narrow, early Tortonian, tidal-dominated, Atlantic-Mediterranean marine passage, Sediment. Geol., 216, 80-90, 2009.

Meijer, P. Th.: A box model of the blocked-outflow scenario for the Messinian Salinity Crisis, Earth Planet. Sci. Lett., 248, 486-494, 2006.

Meijer, P. Th.: Hydraulic theory of sea straits applied to the onset of the Messinian Salinity Crisis, Mar. Geol., 326-328, 131-139, 2012.

Meijer, P. Th. and Dijkstra, H. A.: The response of Mediterranean thermohaline circulation to climate change: a minimal model, Clim. Past, 5, 713-720, doi:10.5194/cp-5-713-2009, 2009.

Meijer, P. Th. and Krijgsman, W.: A quantitative analysis of the desiccation and re-filling of the Mediterranean during the Messinian Salinity Crisis, Earth Planet. Sci. Lett., 240, 510-520, 2005.

Meijer, P. Th. and Tuenter, E.: The effect of precession-induced changes in the Mediterranean freshwater budget on circulation at shallow and intermediate depth, J. Marine Syst., 68, 349-365, 2007.

Meijer, P. Th., Slingerland, R., and Wortel, M. J. R.: Tectonic control on past circulation of the Mediterranean Sea: a model study of the Late Miocen, Paleoceanography, 19, 1-19, 2004.

Mellor, G. L. and Yamada, T.: Development of a turbulence closure model for geophysical fluid problems, Rev. Geophys., 20, 851875, 1982.

Mellor, G. L., Ezer, T., and Oey, L. Y.: The pressure gradient conundrum of sigma coordinate ocean models, J. Atmos. Oc. Technol., 11, 1126-1134, 1994.

Myers, P. G.: Flux-forced simulations of the paleocirculation of the Mediterranean, Paleoceanography, 17, 9-1, 2002.

Myers, P. G., Haines, K., and Josey, S.: On the importance of the choice of wind stress forcing to the modeling of the Mediterranean Sea circulation, J. Geophys. Res. (1978-2012), 103, 15729-15749, 1998a.

Myers, P. G., Haines, K., and Rohling, E. J.: Modeling the paleocirculation of the Mediterranean: The Last Glacial Maximum and the Holocene with emphasis on the formation of sapropel S1, Paleoceanography, 13, 586-606, 1998b.

Pérez-Asensio, J. N., Aguirre, J., Schmiedl, G., and Civis, J.: Impact of restriction of the Atlantic-Mediterranean gateway on the Mediterranean Outflow Water and eastern Atlantic circulation during the Messinian, Paleoceanography, 27, PA3222, doi:10.1029/2012PA002309, 2012.

Pratt, L. J. and Spall, M. A.: Circulation and exchange in choked marginal seas, J. Phys. Oceanogr., 38, 2639-2661, 2008.

Roveri, M. and Manzi, V.: The Messinian salinity crisis: Looking for a new paradigm?, Palaeogeogr. Palaeoclimatol. Palaeoecol., 238, 386-398, 2006.

Ryan, W. B. F.: Modeling the magnitude and timing of evaporative drawdown during the Messinian salinity crisis, Stratigraphy, 5, 227-243, 2008.

Samuel, S., Haines, K., Josey, S., and Myers, P. G.: Response of the Mediterranean Sea thermohaline circulation to observed changes 
in the winter wind stress field in the period 1980-1993, J. Geophys. Res., 104, 7771-7784, 1999.

Sanchez-Gomez, E., Somot, S., Josey, S. A., Dubois, C., Elguindi, N., and Déqué, M.: Evaluation of Mediterranean Sea water and heat budgets simulated by an ensemble of high resolution regional climate models, Clim. Dynam., 37, 2067-2086, doi:10.1007/s00382-011-1012-6, 2011.

Sannino, G., Bargagli, A., and Artale, V.: Numerical modeling of the mean exchange through the Strait of Gibraltar, J. Geophys. Res., 107, 9-1-9-24, 2002.

Schneck, R., Micheels, A., and Mosbrugger, V.: Climate modelling sensitivity experiments for the Messinian Salinity Crisis, Palaeogeogr. Palaeoclimatol. Palaeocol., 286, 149-163, 2010.

Seidenkrantz, M.-S., Kouwenhoven, T. J., Jorissen, F. J., Shackleton, N. J., and van der Zwaan, G. J.: Benthic foraminifera as indicators of changing Mediterranean-Atlantic water exchange in the late Miocene, Mar. Geol., 163, 387-407, 2000.

Somot, S., Sevault, F., and Déqué, M.: Transient climate change scenario simulation of the Mediterranean Sea for the twenty-first century using a high-resolution ocean circulation model, Clim. Dynam., 27, 851-879, 2006.

Sonnenfeld, P. and Finetti, I.: Messinian evaporites in the Mediterranean: a model of continuous inflow and outflow, in: Geological Evolution of the Mediterranean Basin, edited by: Stanley, D. J. and Wezel, F.-C., Springer, 347-353, 1985

Soria, J. M., Fernández, J., and Viseras, C.: Late Miocene stratigraphy and palaeogeographic evolution of the intramontane Guadix Basin (Central Betic Cordillera, Spain): implications for an Atlantic-Mediterranean connection, Palaeogeogr. Palaeoclimatol. Palaeoecol., 151, 255-266, 1999.

Stratford, K., Williams, R. G., and Myers, P. G.: Impact of the circulation on sapropel formation in the eastern Mediterranean, Global Biogeochem. Cy., 14, 683-695, 2000.

Thompson, B., Nilsson, J., Nycander, J., Jakobsson, M., and Döös, K.: Ventilation of the Miocene Arctic Ocean: An idealized model study, Paleoceanography, 25, PA4216, doi:10.1029/2009PA001883, 2010.
Topper, R. P. M. and Meijer, P. Th.: A modelling perspective on spatial and temporal variations in Messinian evaporite deposits, Mar. Geol., 336, 44-60, 2013.

Topper, R. P. M., Flecker, R., Meijer, P. Th., and Wortel, M. J. R.: A box model of the Late Miocene Mediterranean Sea: Implications from combined ${ }^{87} \mathrm{Sr} /{ }^{86} \mathrm{Sr}$ and salinity data, Paleoceanography, 26, PA3223, doi:10.1029/2010PA002063, 2011.

Tsimplis, M. N.: Vertical structure of tidal currents over the Camarinal Sill at the Strait of Gibraltar, J. Geophys. Res., 105, 1970919728, 2000.

Tsimplis, M. N. and Bryden, H. L.: Estimation of the transports through the Strait of Gibraltar, Deep-Sea Res. Pt. I, 47, 2219 2242, 2000.

Tuenter, E., Weber, S. L., and Lourens, L. J.: The response of the African summer monsoon to remote and local forcing due to precession and obliquity, Glob. Planet. Change, 36, 219-235, 2003.

van Assen, E., Kuiper, K. F., Barhoun, N., Krijgsman, W., and Sierro, F. J.: Messinian astrochronology of the Melilla Basin: stepwise restriction of the Mediterranean-Atlantic connection through Morocco, Palaeogeogr. Palaeoclimatol. Palaeoecol., 238, 15-31, 2006.

Weijermars, R.: Neogene tectonics in the Western Mediterranean may have caused the Messinian Salinity Crisis and an associated glacial event, Tectonophysics, 148, 211-219, 1988.

Wessel, P. and Smith, W. H. F.: Free software helps map and display data, EOS Transitions AGU, 72, 441-446, 1991.

$\mathrm{Xu}$, X., Chassignet, E. P., Price, J. F., Özgökmen, T. M., and Peters, H.: A regional modeling study of the entraining Mediterranean outflow, J. Geophys. Res., 112, C12005, doi:10.1029/2007JC004145, 2007.

Zavatarelli, M. and Mellor, G. L.: A numerical study of the Mediterranean Sea circulation, J. Phys. Oceanogr., 25, 1384-1414, 1995. 